University of Nebraska - Lincoln

DigitalCommons@University of Nebraska - Lincoln

$1-1997$

\title{
The Roasted and the Boiled: Food Composition and Heat Treatment with Special Emphasis on Pit-Hearth Cooking
}

LuAnn Wandsnider

University of Nebraska - Lincoln, Iwandsnider1@unl.edu

Follow this and additional works at: https://digitalcommons.unl.edu/anthropologyfacpub

Part of the Anthropology Commons

Wandsnider, LuAnn, "The Roasted and the Boiled: Food Composition and Heat Treatment with Special Emphasis on Pit-Hearth Cooking" (1997). Anthropology Faculty Publications. 28.

https://digitalcommons.unl.edu/anthropologyfacpub/28

This Article is brought to you for free and open access by the Anthropology, Department of at DigitalCommons@University of Nebraska - Lincoln. It has been accepted for inclusion in Anthropology Faculty Publications by an authorized administrator of DigitalCommons@University of Nebraska - Lincoln. 
Published in Journal of Anthropological Archaeology 16 (1997) , pp. 1-48.

Copyright (C 1997 Academic Press. Used by permission. http://www.elsevier.com/locate/jaa

Submitted March 1, 1996; revised October 17, 1996; accepted October 20, 1996.

\title{
The Roasted and the Boiled: Food Composition and Heat Treatment with Special Emphasis on Pit-Hearth Cooking
}

\author{
LuAnn Wandsnider \\ Department of Anthropology, University of Nebraska-Lincoln, Lincoln, Nebraska 68588-0368
}

\begin{abstract}
Heat treatment is one of the major ways humans change the composition and chemistry of food tissues, making them more digestible, less toxic, and more durable. This paper reviews salient features of food chemistry and food composition and how heat treatment, especially pit-hearth cooking, affects that composition. Ethnographic accounts of cooking indicate that traditional populations relied on pit-hearth cooking especially to alter the composition of foods high in either lipids or complex carbohydrates. Historically, pit hearths were also used to process large quantities of food. Various kinds of pit hearths figure prominently in the archaeological deposits of the American Great Plains and elsewhere. The implications of this recurring phenomenon are discussed in terms of the coevolution of diet, cooking systems, and the appearance of Neel's "thrifty" genotype.
\end{abstract}

\section{Introduction}

It seems to be a general rule that sciences begin their development with the study of the unusual. They have to develop considerable sophistication before they interest themselves in the common place.

Linton 1994:369

In 1944, Ralph Linton decried the lack of interest shown by anthropologists and archaeologists in common archaeological remains, ceramics, and the associated, equally common pursuits of cooking and food processing. By Linton's reckoning, 50 years later, either our sciences have become much more sophisticated or the commonplace is now perceived as the unusual and therefore worthy of our scrutiny. Certainly today, research on a wide range of anthropological questions relies on or considers variation in food exploitation and processing strategies, including studies of hominid and human evolu- tion (Brace et al. 1987; Jackson 1991; Larsen 1995; Stahl 1984), subsistence change and the origins of food production (contributors to Harris and Hillman 1989; Hayden 1990), the appearance of ceramic container technology (Braun 1983, 1987; Brown 1989; Schiffer and Skibo 1987), and status differences in access to foods with different qualities (e.g., Welch and Scarry 1995).

Recently, Ann Stahl (1989) has considered the fundamental relationship between food chemistry and food processing technology, especially highlighting the changes in food processing that might occur in lieu of subsistence change. This paper attempts to continue Stahl's work, focusing expressly on the relationship between food chemistry and cooking strategies that involve heat treatment. Where Stahl addressed her work to the naive assumptions made about the costs and benefits of food processing in optimal foraging calculations, I am interested in assembling a body of reference knowledge (1) that will further our appreciation of the selective use of specific 
cooking technologies and (2) that will make more accessible to anthropology the richness of the archaeological record, dominated by the durable remains of cooking systems (i.e., ceramic, stone, and basket containers; varieties of hearths, ovens, and heat reservoir elements), for approaching important anthropological issues. Thus, this paper focuses on the food processing strategy of heat treatment and considers the circumstances in which, for example, root baking is selected over root boiling, pit-roasting over spit-roasting.

Heat treatment is just one of a number of cooking strategies available to people and so I begin with an overview of cooking and cooking systems. One of several factors that influences the design of cooking systems is that of food composition and an abstract of this body of knowledge, as it relates to thermal food processing, is developed in the succeeding section. Given this understanding of food chemistry and in light of the digestive capabilities of anatomically modern humans, an evaluation of several expectations for the heat treatment of food by traditional populations follows. In order to understand the special conditions under which they are used, I next focus on the pit hearth and related cooking technologies. The paper concludes by highlighting the special role of one heat treatment system, pit-hearth cooking, for understanding the appearance and maintenance of Neel's $(1962,1982)$ "thrifty" genotype in association with complexes of noncereal foods and related cooking systems, especially on the Great Plains of North America.

\section{Cooking and Cooking Systems}

Ultimately, cooking entails manipulating the temperature, moisture, and $\mathrm{pH}$ regime of food as well as its surface area so that specific, desirable physical and chemical changes can take place. Nutritionists and others (Penfield and Campbell 1990; Stahl 1989) tell us that by processing tissues in this way, people may do one (or all) of several things. They advance the digestion process, so that more energy and nutrients can be obtained from any one mouthful of food. They may reduce the chance of illness by killing food-borne bacteria and parasites and by eliminating toxins that occur or develop in some tissues. And, by cooking, spoilage bacteria are eliminated and water, needed by bacteria to grow, is reduced, so that the storage life of food may be extended.

Cooking encompasses many activities (Medved 1986; Penfield and Campbell 1990; Stahl 1989). It may entail mechanically grinding or pulverizing tissues to increase the surface area over which various physical or chemical processes operate. Food preparation may involve flushing and rinsing plant tissues. Foods may be fermented or partially digested by cultivated bacteria to break larger components into smaller, digestible components. People may bathe food tissues in salty or acidic solutions to induce chemical changes. Parching, broiling, spit-roasting, baking, and frying are examples of dry heat cooking. Moist thermal treatments include braising, stewing, or boiling. Given this range of food preparation techniques and tools, why is one suite or sequence of cooking activities executed rather than another?

Undoubtedly, many different factors influence the design of a specific cooking system and the implementation of specific cooking strategies (Figure 1). For example, the BTUs provided by an available fuel source, be it seal blubber, grass blades, or wood, will constrain the cooking environment, as will the availability and nature of containers. Whether food is to be processed for storage or for immediate consumption stipulates the sequence and nature of cooking activities (Stahl 1989; Turner et al. 1990:30). If a large number of hands are available, the cooking system may be designed to accommodate simultaneous root harvesting, fuel collection, and oven construction. If other duties must be met and little time for food preparation is available, people may draw from previously processed readyto-eat foods. And, as Stahl (1989) has recently emphasized in her review of food chemistry of cooking strategies, in designing their cooking systems, people may be attempting to maximize 


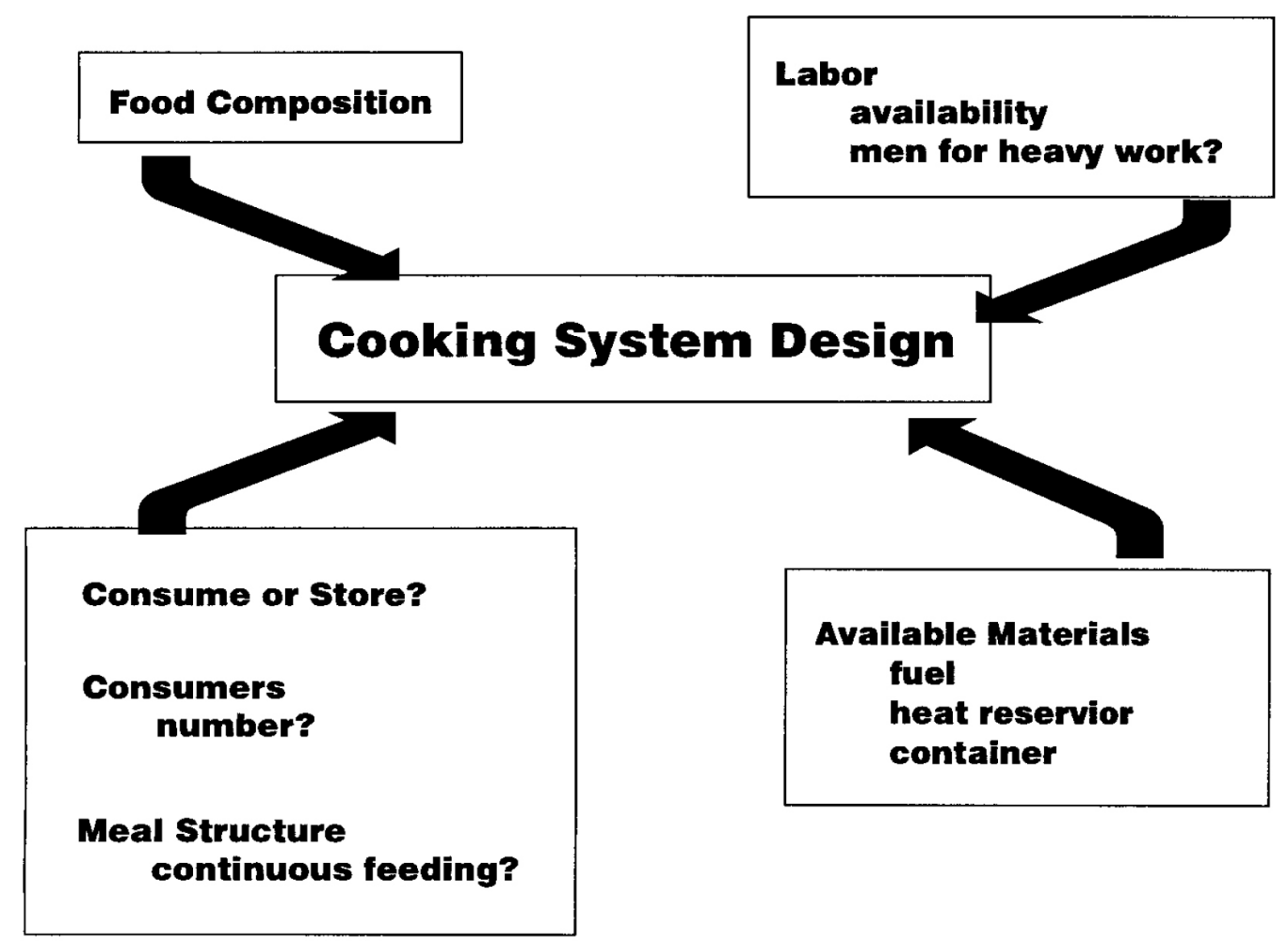

Figure 1. Cooking system design parameters.

nutrient value, minimize toxins, or compromise these two ends.

Food chemistry is but one of the factors that people consider in designing their cooking systems. Heat treatment is but one of the strategies available for altering tissues. The following sections consider the relationship between the two.

\section{Food Composition and Thermal Processing}

As already mentioned, the thermal processing has three effects on food (Penfield and Campbell 1990): increasing its nutrient density; detoxifying it and removing pathogens and other sources of illness; and, extending its shelf life. (Of course, cooking also enhances the flavor of foods, an observation that begs the question of how selection operated to make some processed foods palatable to humans and others not.) The selection of a particular heat treatment depends on which several of these three effects is desired and, equally importantly, on the physical and chemical properties of the raw tissues.

\section{Heat Treatment Effects}

Extrasomatically advance digestion. To understand how cooking advances digestion, we need first to understand raw tissue composition and the form in which those tissue components must be in order to be absorbed into the human bloodstream. Food tissue is composed of proteins, carbohydrates, lipids, minerals, enzymes, and water. The tissue polymers of protein, carbohydrates, and lipids within food vary in their complexity and in the nature and strength of the links between constituent units. For example, $98 \%$ of the carbohydrates found in dried figs are in the form of simple sugar, while only $6 \%$ of the carbohydrates in white potatoes are in this form (Briggs and Calloway 1984:27, Table 2-1). Significantly, only small and simple polymers are absorbed within the small intestine. There- 
fore, complex or large carbohydrates, proteins, and lipids must be broken down by chemical or physical processes into smaller polymers.

Hydrolysis is one process by which complex molecules are cleaved into smaller molecules through the uptake of a water molecule. In the gastrointestinal tract, the long, complex molecules of the protein, carbohydrates, and lipids are hydrolyzed to more fundamental constituents by digestive enzymes. It is these fundamental units that are absorbed and used for a variety of tasks, e.g., oxidized to provide energy, or remodeled for use in enzymes or for structural purposes. Because, however, of how digestion is regulated by the body and the nature of the chemical bonds that join the fundamental units, not all proteins, carbohydrates, and fats that make it through the small intestine are broken down into the simpler polymers needed by the body. In general, carbohydrate-rich foods move through the alimentary tract faster than proteinrich foods, which in turn move faster than fatty foods; foods with a mixture of proteins and fats leave the stomach even more slowly (Briggs and Calloway 1984:97).

By beginning the hydrolysis process extrasomatically, more of the complex polymers in plant and animal tissues can be broken down to the simple form required by the body, leaving the digestive system to complete the process. Hydrolysis of some tissues, which the body accomplishes at low temperatures and with the help of digestive enzymes, can also be accomplished by exposing tissues to heat, as well as by subjecting them to acid or salt baths, or by some combination of the preceding. In other words, cooking increases the energy value or energy density of the tissues. As discussed below, however, different food polymers have different temperature thresholds at which hydrolysis occurs.

Reduce pathogens, harmful microorganisms, and toxins. Food microorganisms or the toxins they produce may cause illness upon inges- tion. Both the microorganism and its associated toxin, however, may be controlled by heat treatment or by changing the acidity or salt content of the food product. For Staphylococcus aureus and Salmonella sp., in meat products, and Clostridium botulinum, in plant and animal products, temperatures above $50^{\circ} \mathrm{C}$ are effective at reducing the risk of illness (Penfield and Campbell 1990:257-263).

In addition, plants make use of a wide variety of secondary compounds to defend themselves from predation by insects and other herbivores. These compounds, including alkaloids, glycosides, and phenolics, and others have lethal or sublethal effects if ingested (Leopold and Ardrey 1972; Ames 1983; Jackson 1991). We humans register foods with many of these compounds as bitter or unpalatable and have devised an elaborate series of procedures for detoxifying them, as reviewed by Johns and Kubo (1988). For example, protein-based toxins in many seeds may be degraded by exposing them to heat; the proteins become denatured (see below) and are unable to perform (Leopold and Ardrey 1972:512). Volatile fatty acids, like the cyanogens occurring in manioc and the cabbage family, are oxidized when exposed to heat (Leopold and Ardrey 1972:512). In the case of many roots (Johns 1989:505), however, the secondary compounds are neither of these and heat treatment is therefore not useful. Indeed, in some potatoes, heat does not destroy the compound and may in fact enhance the level of glycoalkaloids, creating a variety of neurological and gastrointestinal problems (Johns 1989; Jackson 1991:517). For many root foods, thus, other detoxification procedures are followed. In the case of agave use throughout northern Mexico, especially toxic subspecies were known and avoided (Gentry 1982:6). Tissue portions especially high in toxins were rubbed or scraped away (Johns and Kubo 1988). And, as in the case of cheeky yam used by Aborigines in northern Australia, the toxins may be dissolved and washed from the tissue (O'Dea 1991:237). 
Food preservation. Food preservation practices are designed to reduce or delay enzymatic and microbial changes in food and can be achieved in many ways. For example, blanching (brief immersion in boiling water or steam) reduces enzymatic activity by inactivating the constituent proteins. Pasteurization destroys some pathogenic and spoilage organisms while sterilization kills almost all microorganisms (Penfield and Campbell 1990:266 -271). And, by increasing or decreasing the acidity of foods, the optimal $\mathrm{pH}$ required by certain microorganisms is changed and so they die.

Many seeds and nuts are rich in lipids and also lipases, which are naturally occurring enzymes that catalyze lipid hydrolysis. While lipid hydrolysis results in more digestible shorter-chain fatty acids, it also results in, for stored nuts or seeds, the accumulation of free fatty acids and a variety of carcinogens (Ames 1983:1258), not to mention a rancid flavor. Brief exposure to heat disables lipase and therefore enables the long-term storage of seeds and nuts (Penfield and Campbell 1990:341).

Water, especially unbound or freely available water, is critical for most of the biological, chemical, and physical changes that tissues undergo. By reducing tissue water content, or by binding water to the chemical structure of the tissue, e.g., by adding sucrose, salt, or glycerol, the growth of bacteria, molds, and yeasts is arrested and enzymatic activity drops (Penfield and Campbell 1990:99-101).

Thus, heat treatment directly destroys potential spoilage microorganisms, deactivates protein-based enzymes that might cause the degradation of the tissue, and removes a component vital to the actions of spoilage agents, water.

\section{Food Composition and Thermal Processing}

Given this overview of the effects of heat treatment on tissues, let us look more closely at the composition of food and how manipulation of its composition through heat treatment results in these effects. The following technical presen- tation highlights (1) the temperatures required to promote the desired effects, (2) the necessary the moisture regime, and (3) when available, the rate at which these transformational processes occur. These parameters are especially important for understanding the design of cooking systems and have implications for the archaeological manifestation of the cooking regime. It is useful to consider foods in terms of the constituents of carbohydrates, lipids, and proteins.

Carbohydrates. Carbohydrates occur primarily in plant tissues and comprise sugar, sugar alcohols, reserve or storage polysaccharide (used by plants to store energy), and structural polysaccharide (which make up cell walls). The latter, the structural saccharides, include cellulose and pectin and are commonly glossed as dietary fiber. Simple sugars include glucose and fructose, among others, and are found in fruits and vegetables.

The reserve polysaccharides include starch, a glucose polymer, and, in about $15 \%$ of the world's flora (Hendry and Wallace 1993:136), fructan, a polymer of fructose and a single glucose residue. Starches are found in cereals such as rice and corn and in roots such as potatoes and taro. Jerusalem artichoke and chicory are two commercially exploited sources of fructans; Table 1 lists other fructan-bearing plants used by humans today and in the past. Fructan is a much more readily tapped energy reserve in plants than is starch and seems to be a preferred storage form in semiarid and temperate areas where sudden changes in growing conditions occur (Pollack and Chatterton 1988:135-136).

The heat treatment of carbohydrates is predominantly concerned with enhancing digestion and reducing water content so that they can be stored. In addition, carbohydrate-rich seeds may contain protein-based secondary compounds, which can be detoxified as discussed for protein in general, below.

The digestibility of a carbohydrate is related to its polymer size and structure. Simple sugars are small enough polymers that they are read- 
Table 1a. Fructan-Containing Plants in Monocotyledonous Families Identified as Food (or Other) Plants by Incoll and Bonnett (1993: 316, Table 3) and Others (see References)

\begin{tabular}{|c|c|c|c|c|}
\hline Plant & $\begin{array}{l}\text { Common } \\
\text { name }\end{array}$ & $\begin{array}{l}\text { Edible (other) } \\
\text { part }\end{array}$ & $\begin{array}{l}\text { Chemistry } \\
\text { (structure; DP) }\end{array}$ & Reference \\
\hline \multicolumn{5}{|l|}{ Liliaceae } \\
\hline Allium ampeoprasum & $\begin{array}{l}\text { Leek, } \\
\text { great- } \\
\text { headed } \\
\text { garlic }\end{array}$ & Leaf, bulb & & \\
\hline Allium сера & $\begin{array}{l}\text { Onion, } \\
\text { shallot }\end{array}$ & Bulb & DP3-12 (跑) & $\begin{array}{l}\text { Darbyshire and Henry } \\
\text { (1981) }\end{array}$ \\
\hline Allium porrum & Leek & Bulb & DP3-12 (DP12) & $\begin{array}{l}\text { Darbyshire and Henry } \\
\text { (1981) }\end{array}$ \\
\hline Allium sativum & Garlic & Bulb & Inulin; DP3-50 & $\begin{array}{l}\text { Darbyshire and Henry } \\
\text { (1981) }\end{array}$ \\
\hline Asparagus racemosus & & Tuber & & \\
\hline $\begin{array}{l}\text { Arthropodium aff. } \\
\text { milleflorum }\end{array}$ & & Tuberous roots & Neokestose; DP4 & Incoll et al. (1989) \\
\hline Asphodelus aestivus & Asphodel & Tuberous root & & \\
\hline Bulbine bulbosa & & Corm & Inulin; DP3-5 (距) & Incoll et al. (1989) \\
\hline Caesia calliantha & & Tuberous root & $\begin{array}{l}\text { Inulin; DP3->5 } \\
\quad(\mathrm{DP}>5: 41 \%)\end{array}$ & Incoll et al. (1989) \\
\hline Camassia Camas & & Bulb & Inulin & $\begin{array}{l}\text { Yanovsky and } \\
\text { Kingsbury (1938) }\end{array}$ \\
\hline Dichopogon strictus & & & $\begin{array}{l}\text { Neokestose; DP3->5 } \\
(\mathrm{DP}>5: 89 \%)\end{array}$ & Incoll et al.(1989) \\
\hline $\begin{array}{l}\text { Erythronium } \\
\text { gradiflorum }\end{array}$ & Glacier lily & Corm & Inulin & Turner et al. (1990:122) \\
\hline \multicolumn{5}{|l|}{ Agavacae } \\
\hline Agave vera cruz & Agave & Meristem & Branched; DP32 & Meier and Reid (1982: 447) \\
\hline Cordyline terminalis & Palm lily & Tuber & Branched; DP15 & Meier and Reid (1982: 449) \\
\hline Dracaena australis & & Tuber & & \\
\hline Yucca filamentosa & & (Stem) & & \\
\hline
\end{tabular}

a Underlined values indicate a dominant degree of polymerization in the raw state.

ily absorbed into blood vessels in the small intestine. In contrast, the structural carbohydrates are undigestible by alimentary enzymes, but some are broken down by bacteria in the large intestine. The reserve polysaccharides similarly resist digestion. With heat treatment, however, starches and fructans are affected both physically and chemically and become more digestible.

Upon exposure to moist heat, starch granules experience the physical transformations of ge- latinization and pasting. As heat is applied, the starch granule swells with water (gelatinization) and, if held at high temperatures (below $95^{\circ} \mathrm{C}$ for most starches) for several minutes, eventually implodes (pasting). Upon rupturing, granule integrity is lost and amylose, one of two starch fractions, is released. Ruptured starch molecules are much more susceptible to hydrolysis by digestive enzymes than are intact starch granules (Greenwood and Munro 1979b:385387). In addition, dextrinization, the hydrolysis 
Table 1b. Fructan-Containing Plants in Dicotyledonous Families Identified as Food (or Other) Plants by Incoll and Bonnett (1993: 318, Table 4) and Others (See References)

\begin{tabular}{|c|c|c|c|c|}
\hline Plant & Common name & $\begin{array}{l}\text { Edible (other) } \\
\text { part }\end{array}$ & $\begin{array}{l}\text { Chemistry } \\
\text { (structure; DP) }\end{array}$ & Reference \\
\hline \multicolumn{5}{|l|}{ Asteraceae } \\
\hline Arctium lappa & Edible burdock & Tap root & & \\
\hline Cichorium intybus & Chicory & Taproot & $\begin{array}{l}\text { Inulin; in cultivars, } \\
\text { DP > } 10 \text { (70\% mass) }\end{array}$ & Vukov et al. (1993:341) \\
\hline Cirsium oleraceum & Meadow cabbage & Taproot & & \\
\hline Helianthus tuberosus & $\begin{array}{l}\text { Jerusalem } \\
\text { artichoke }\end{array}$ & Tuber & $\begin{array}{l}\text { Inulin; in cultivars, } \\
\text { DP > } 10 \text { (50\% mass) }\end{array}$ & Vukov et al. (1993:341) \\
\hline Inula helenium & Elecampane & Root & Inulin & \\
\hline Microseris lanceolata & Murnong & Tuberous root & DP > 5 (91\% mass) & Incoll et al. (1989) \\
\hline Polymnia sonchifolia & Yacon & Tuber & DP3-10 & Ohyama et al. (1990) \\
\hline Scorzonera hispanica & Black salsify & Taproot & & \\
\hline Taraxacum officccinale & Dandelion & Taproot & Inulin & $\begin{array}{l}\text { Yanovsky and } \\
\text { Kingsbury (1938) }\end{array}$ \\
\hline \multicolumn{5}{|l|}{ Campanulaceae } \\
\hline Campanula rapanculus & Rampion & Taproot & & \\
\hline \multicolumn{5}{|l|}{ Boraginaceae } \\
\hline Symphytum officinale & Comfrey & Leaf & & \\
\hline
\end{tabular}

of starch molecules into dextrin (shorter starch molecules) and maltose, occurs upon exposure to an intense, dry heat.

A similar kind of hydrolysis occurs during digestion through the actions of enzymes in saliva and pancreatic fluids. Thermal processing, however, appears to significantly advance gelatinization and dextrinization of the root starches, thereby increasing their energy value (Greenwood and Munro 1979b). For example, Hellendoorn and colleagues (1970) report that only $10 \%$ of raw potato starch is digestible but that after 15 min of cooking, $75 \%$ is digestible; after $40 \mathrm{~min}$ of cooking, $90 \%$ is digestible. In the case of foods with higher proportions of the amylose (as opposed to the other starch faction, amylopectin), gelatinization occurs at relatively high temperatures (compare data presented in Greenwood and Munro 1979b) and these same foods appear to have longer digestion times (Thorburn et al. 1987:105). As discussed below, many bushfoods from arid and semiarid areas appear to be of this variety and may therefore require extensive heat treatment to be maximally digestible.

Fructan is the other, less familiar, reserve carbohydrate. In humans, two of the four forms it is commonly found in, inulin and levan, cannot be digested by acid hydrolysis or by enzymes in the human stomach or small intestine (Hendry and Wallace 1993:128). Instead, these fructans pass into the colon where they are almost completely metabolized by bifidobacteria. Nevertheless, only about $50 \%$ of the potential energy in uncooked fructan is available to humans. There are several benefits, however, to consuming raw fructan-rich foods, which may have been important to traditional populations. First, its use by bifidobacteria in the colon suppresses the production of intestinal putrefactive substances, relieving constipation (but also producing flatulence). Second, for modern populations, the fact that it is sweet to the taste but contributes relatively few calories (Incoll and Bonnett 1993:309; Roberfroid 1993:105, 132-133; Vogel 1993:66-67) makes it an attractive food component. 


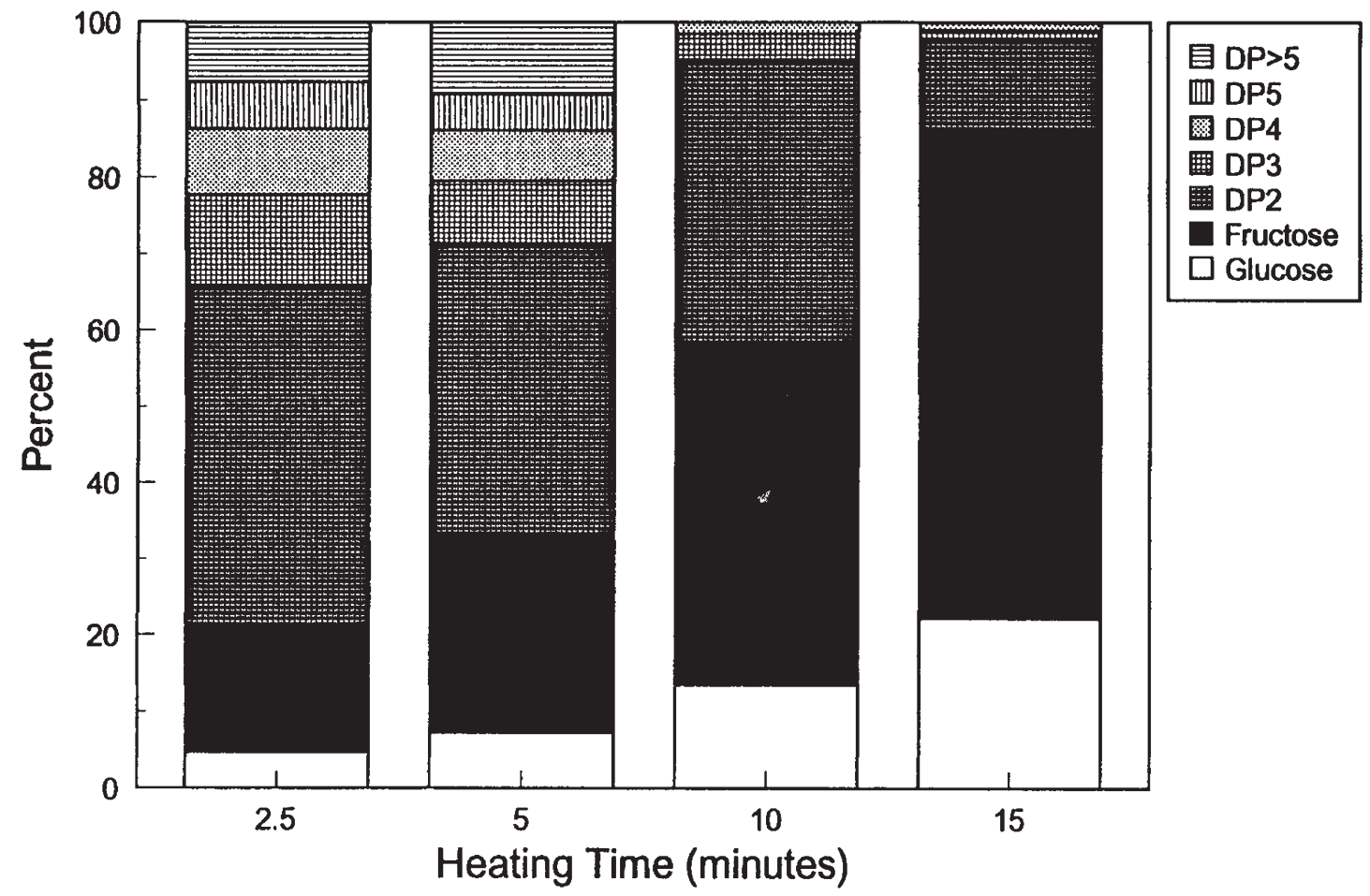

Figure 2. Percentage composition of Jerusalem artichoke syrup heated for varying lengths of time at $100^{\circ} \mathrm{C}$ and $\mathrm{pH} 2.5$; data from Yamazaki and Matsumoto (1993:357).

Additionally, we can also speak of the nutritional benefits of consuming hydrolyzed inulin. Through the application of heat (and manipulation of $\mathrm{pH}$ ), inulin can be depolymerized (i.e., its polymer length reduced) and hydrolyzed. Figure 2, for example, illustrates the hydrolysis of a Jerusalem artichoke syrup as heat is applied for varying lengths of time. The degree of polymerization (DP; polymer length) decreases over time while the number of fructose (and glucose) residues simultaneously increases. Pit-baking produces the same result; Malouf (1979:37) reported that pit-baked camas resulted in a fructoserich product. Fructose is one of the simple sugars (along with glucose) that is readily digested by humans. It is about twice as sweet as glucose and 1.6-1.8 times sweeter than sucrose (common table sugar; Greenwood and Munro 1979a:40); many accounts of the traditional processing of inulin-rich foods emphasize the very sweet nature of the final product. In the past, people made use of these same principles of food chemistry to realize up to a $100 \%$ increase in the energy available from fructan-bearing plants.
In addition to advancing tissue digestion, the heat treatment of carbohydrate-rich foods also results in a more storable food product because of water loss. Through dehydration, water is either lost or so bound to other molecules that it is effectively unavailable to bacteria and other microorganisms. For this reason, dehydrated fruits and other carbohydrate-rich foods can be stored without spoiling for great lengths of time.

Lipids. Simple fats are composed of glycerol and up to three fatty acids and are found in both plant and animal tissues. Polymer length and the degree to which that fatty acids have bonded or become saturated with hydrogen are especially important in determining their digestibility. Short-chain fatty acids are better absorbed than long-chain fatty acids, as are unsaturated fats compared with saturated fats (Briggs and Calloway 1984:104).

Heat treatment of fatty foods seems to have four goals, which are consistent with the overall effects of food preparation. First, subjecting moist foods to high temperatures, as in pan frying, results in lipid hydrolysis (Penfield and 
Campbell 1990:341-342). Lipid hydrolysis involves breaking the ester linkage between glycerol and a fatty acid and requires one molecule of water for every ester linkage that is broken. The resulting glycerols and short-chain fatty acids are more digestible (Briggs and Calloway 1984:99).

Second, as noted above, heat may be used to inactivate or denature enzymes, such as lipases, that catalyze undesired lipid hydrolysis and rancidity. The low heat, dry roasting of piñon nuts thus conserves the food value and flavor of the nuts during storage.

Other effects of heating fats concern fat recovery, reducing cooking time, and preparing flavorful and more chewable foods. Shortchain fatty acids have lower melting points than long-chain fatty acids and are therefore more likely to be liquid at room temperatures. And, fatty acids that are maximally saturated with hydrogen have a higher melting point than do unsaturated fatty acids (McWilliams 1993:263 -266). In general, lipids of a plant origin are rich in unsaturated fatty acids, while those from domesticated animals contain substantial amounts of saturated fatty acids (Medved 1986:108); animals that are free to select their diet, however, appear to deposit relatively more unsaturated fats, compared with domesticated animals (Crawford 1968; Crawford et al. 1970).

The melting point of lipids is of concern here because it has implications for the recovery of those lipids, especially by traditional populations in generally fat-poor environments. Oils are extracted from plant tissues with presses or hot baths. To extract solid fats, which are composed of crystals in oil, the crystal-to-liquid ratio must be reduced using heat so that the lipid can be expressed from the tissue. Traditional populations exploited this feature to render fat from muscle tissues and bones. Similar techniques are commercially used today to produce pork lard using steam and beef tallow using dry heat (Penfield and Campbell 1990:348).
Finally, upon heating, the fat in tissues disperses. This dispersion appears to contribute to the rapid transfer of heat throughout foods (Holmes and Woodburn 1981:272- 273). Also, dispersion results in meats that are perceived as both flavorful and tender, although both the reason for this tenderness and its relationship with lipid hydrolysis are still being researched (Penfield and Campbell 1990:196).

Proteins. Proteins are large complex chains of amino acids found in animal tissues, milk, eggs, and legumes. Again, small chains of amino acids can be further broken down in the modern human alimentary tract; large chains may pass through the alimentary tract only partially digested.

Heat, unsurprisingly, helps in several ways to make protein-bearing foods more nutritious and also less likely to induce sickness than uncooked protein. Exposed to heat, protein becomes denatured, that is, the protein peptide chain unfolds as weaker bonds responsible for the structure of the protein molecule give way (Penfield and Campbell 1990:111, 190-192). Unfolded or denatured protein is more readily chewed (Brace et al. 1987), hydrolyzed, and has increased solubility. It is thus more easily digested by proteolytic enzymes (FAO 1990:75) and resolved to its component amino acids.

Muscle protein becomes denatured with exposure to temperatures between 40 and $60^{\circ} \mathrm{C}$. At higher temperatures (for beef, those above $60^{\circ} \mathrm{C}$ ), the myofibullar proteins coagulate and lose their water-holding capacity; we perceive muscle fibers cooked at high temperatures as tough. Also, at higher temperatures, critical amino acids such as cystonine are destroyed. High-quality muscle fiber, then, requires little exposure to heat.

Muscles also contain, however, several connective tissues that support muscle fiber and attach the muscle to bone. Collagen is one of these connective tissues and it, too, is composed of protein. When heated, collagen fibers denature and contract; we perceive lightly cooked collagen- 
rich meat as being tough. But, when heated to temperatures higher than $65^{\circ} \mathrm{C}$ in the presence of water, collagen is hydrolyzed to gelatin, thereby making the meat more tender overall (Penfield and Campbell 1990:194-195).

The location of the muscle on the body and the degree to which it is exercised influences the amount of connective tissue present and, therefore, the preparation of the tissue. For this reason, the darker meats in chicken, for example, are tougher than the white meat. While the amount of connective tissue is the same in younger and older animals, the number and strength of bonds between peptide chains are greater in older animals; thus, meat from older animals is tougher than that from younger animals and requires longer cooking (Penfield and Campbell 1990:194-195). Other factors such as the amount of bone present, the fiber density (high in young animals, lower in adults), and fat content influence the time it takes for the internal temperature of a piece of meat to increase and, therefore, for protein denaturation to occur (Holmes and Woodburn 1981).

Thus, as most cooks know (Rombauer and Becker 1975:450-452), preparation of muscle fiber to optimize its food value depends on the size of the animal, its age, and the amount of connective tissue present. Muscle with little collagen, such as that attached to the dorsal portion of the spine on a large quadruped, needs only a brief exposure to moderate temperatures; broiling, pan-frying, and roasting suffice in this case. When more connective tissue is present, as will be true for most carcasses of wild species, then a longer exposure to moist heat is needed to convert the collagen to gelatin; i.e., braising and stewing is recommended (Medved 1986:232).

Besides making muscle protein more chewable through denaturation, other applications of protein denaturation are important to traditional populations. Denaturing lipases, which are composed of amino acids and which might induce lipid hydrolysis, is one example. In addition, denaturing bacteria and parasites so that they are unable to perform is another. Finally, denaturing the protein-based enzymes responsible for producing toxins in seeds especially is a final important application (Leopold and Ardrey 1972:512; Johns 1989:505).

In sum, food tissues with different compositions require cooking systems with specific parameter values to promote tissue digestion; to denature and destroy bacteria, microorganisms, and toxins; and to reduce the water content of food to be stored. Table 2 summarizes the information presented above in terms of cooking regime and the effects on tissues treated in this fashion.

\section{Stewed, Roasted, Boiled, Dried: Patterns in Food Processing}

In light of the body of reference knowledge assembled above, we are in a position to examine and appreciate some of the variation observed in ethnographically documented traditional cooking systems. Relatively comprehensive, but underdetailed, surveys of food preparation techniques are available for several North American hunter-gatherer and agricultural groups, as listed in Table 3. An examination of the traditional methods used by these groups to prepare animal and plant foods suggests that specific heat treatment methods were effective in maximizing food energy density and producing other desirable effects.

Focusing first on animal foods, Table 4 presents proximate analyses of muscles by species, focusing on water, protein, and lipid content. Also listed is a lipid-to-protein ratio, calculated by dividing the lipid by the protein mass. Two series are represented. The first, from Anderson (1989), is based on raw tissues and involves mean values computed over more than a few specimens. The second comes from Kuhnlein and colleagues (1994) and is based on samples taken from animals that had been killed and heat treated using traditional techniques by Sahtú Dene and Métis individuals. For none of these animals do 
Table 2. Heat Treatment Model

\begin{tabular}{|c|c|c|}
\hline \multirow{2}{*}{$\begin{array}{l}\text { Heat source } \\
\text { temperature }\end{array}$} & \multicolumn{2}{|c|}{ Moisture content } \\
\hline & Dry & Moist \\
\hline Very low $\left(.40^{\circ} \mathrm{C}\right)$ & $\begin{array}{l}\text { Sun drying: detoxification, } \\
\text { dehydration }\end{array}$ & \\
\hline Low $\left(40-55^{\circ} \mathrm{C}\right)$ & $\begin{array}{l}\text { Sun/fire drying: detoxification, } \\
\text { dehydration }\end{array}$ & \\
\hline Medium $\left(55-95^{\circ} \mathrm{C}\right)$ & $\begin{array}{l}\text { Roasting: protein denaturation } \\
\text { (large portion; long time) }\end{array}$ & $\begin{array}{l}\text { Boiling: starch gelatinization, pasting; } \\
\text { Stewing/Pot Roasting: collagen hydrolysis, } \\
\text { lipid hydrolysis }\end{array}$ \\
\hline $\begin{array}{l}\text { High }\left(.95^{\circ} \mathrm{C}\right) \\
\text { denaturation; }\end{array}$ & $\begin{array}{l}\text { Broiling: protein denaturation } \\
\text { (small portion; short time); } \\
\text { Baking: dextrinization, } \\
\text { inulin hydrolysis }\end{array}$ & $\begin{array}{l}\text { Blanching (short exposure): bacteria } \\
\text { Pasteurization (medium exposure): } \\
\text { detoxification, enzyme denaturation; } \\
\text { Sterilization (long exposure): detoxification, } \\
\text { microorganism denaturation }\end{array}$ \\
\hline
\end{tabular}

we have information on season of death, age, or sex. Yet, as compiled by Speth and Spielmann (1983:9-12), we know that carcass fat levels may vary as much as $200-500 \%$ during an annual cycle, depending on individual species, pregnancy, and so forth. The degree to which muscle lipid levels and total carcass fat are coupled and thus the degree to which large seasonal variations occur in muscle lipids are unclear. Table 4 seems to indicate that such variation may occur (compare rabbit values in each series); however, it may be owed to seasonal variation in fat content or compositional variation among subspecies. ${ }^{1, *}$

For the purposes of this discussion, I will simply note that several species-bear, muskrat, opossum, horse, and beaver-appear to display rather higher lipid-to-protein values; the other species, i.e., elk, moose, and so forth, display lower values. In Tables 5 and 6, the designations of "high lipid content" and "low lipid content" follow from this pattern. In addition, the ethnographic accounts at times clearly refer to the fatty nature of specific animals such as ground-hog, otter, and badger; this information was used to indicate "suspected lean" or "suspected fatty" meats when analytic information on lipid content could not be found.

\footnotetext{
* See Notes section at end of pages for all footnotes.
}

Table 3. Ethnographic Surveys of Food and Food Preparation

\begin{tabular}{ll}
\hline Group & Reference \\
\hline Acoma/Laguna & Castetter (1935) \\
Coeur d'Alêne & Teit (1930a, 1930b) \\
Plains Cree & Mandelbaum (1979) \\
Dakota & Gilmore (1919) \\
Flathead/Kutenai & Hart (1976) \\
Isleta & Castetter (1935) \\
Mescalero & Basehart (1974) \\
Navajo & Castetter (1935) \\
Nez Perce & Hart (1976); Spinden (1964) \\
Omaha/Ponca & Gilmore (1919) \\
Owens Valley Paiute & Steward (1993) \\
Sun Valley Paiute & Kelly (1932) \\
Pawnee & Gilmore (1919) \\
Pima & Russell (1908) \\
Sanpoi, Nespelem & Ray (1932) \\
Northern Shoshone & Lowie (1909) \\
Tarahumar & Pennington (1963) \\
Tepehuan & Pennington (1969) \\
Tewa, Hopi & Castetter (1935) \\
Thompson Indians & Turner et al. (1990) \\
Winnebago & Gilmore (1991) \\
&
\end{tabular}


Table 4. Proximate Compositional Analysis of Protein-Rich Tissues, Ordered by Lipid/Protein Ratio

\begin{tabular}{|c|c|c|c|c|c|c|c|c|c|c|}
\hline \multirow[b]{3}{*}{ Common name } & \multicolumn{9}{|c|}{ Tissue component (/100 g muscle $)^{\mathrm{a}}$} & \\
\hline & \multicolumn{5}{|c|}{$\begin{array}{l}\text { Raw (or laboratory heat treatment) } \\
\text { (Anderson 1989) }\end{array}$} & \multicolumn{5}{|c|}{$\begin{array}{c}\text { Traditional selection and heat treatment } \\
\text { (Kuhnlein et al. 1994: 151) }\end{array}$} \\
\hline & $N$ & $\begin{array}{c}\mathrm{H}_{2} \mathrm{O} \\
(\mathrm{g}) \\
\end{array}$ & $\begin{array}{l}\text { Protein } \\
(\mathrm{g})\end{array}$ & $\begin{array}{l}\text { Lipid } \\
(\mathrm{g})\end{array}$ & $\begin{array}{l}\mathrm{L} / \mathrm{Pb}^{\mathrm{b}} \\
\text { ratio }\end{array}$ & $N$ & $\begin{array}{c}\mathrm{H}_{2} \mathrm{O} \\
(\mathrm{g}) \\
\end{array}$ & $\begin{array}{l}\text { Protein } \\
(\mathrm{g})\end{array}$ & $\begin{array}{c}\text { Lipid } \\
(\mathrm{g})\end{array}$ & $\begin{array}{l}\mathrm{L} / \mathrm{P}^{\mathrm{b}} \\
\text { ratio }\end{array}$ \\
\hline Raccoon & 1 (cooked) & 54.3 & 29.2 & 14.5 & 0.49 & & & & & \\
\hline Bear & 1 (cooked) & 53.55 & 32.42 & 13.39 & 0.41 & 1 & 73 & 22 & 4 & 0.18 \\
\hline Muskrat & 4 & 69.35 & 20.76 & 8.1 & 0.39 & 2 & 68 & 25 & 4 & 0.16 \\
\hline Opossum & 1 (cooked) & 58.3 & 30.2 & 10.2 & 0.34 & & & & & \\
\hline Horse & 119 & 72.63 & 21.39 & 4.6 & 0.22 & & & & & \\
\hline Beaver & 3 & 70.97 & 24.05 & 4.8 & 0.20 & 2 & 75 & 19 & 5 & 0.26 \\
\hline Boar & 2 & 72.54 & 21.51 & 3.33 & 0.15 & & & & & \\
\hline \multirow[t]{2}{*}{ Caribou } & 30 & 71.45 & 22.63 & 3.36 & 0.15 & $6^{c}$ & 73 & 23 & 1.9 & 0.08 \\
\hline & & & & & & $2^{\mathrm{d}}$ & 75 & 23 & 1.5 & 0.07 \\
\hline Squirrel & 16 & 73.83 & 21.23 & 3.21 & 0.15 & & & & & \\
\hline Deer & 33 & 73.57 & 22.96 & 2.42 & 0.11 & & & & & \\
\hline Goat & 92 & 75.84 & 20.6 & 2.31 & 0.11 & & & & & \\
\hline Rabbit & 30 & 74.51 & 21.79 & 2.32 & 0.11 & 2 & 72 & 26 & 1.2 & 0.05 \\
\hline Antelope & 54 & 74.08 & 22.38 & 2.03 & 0.09 & & & & & \\
\hline Bison & 33 & 74.57 & 21.62 & 1.84 & 0.09 & & & & & \\
\hline Bison $^{\mathrm{e}}$ & 30 & 74.5 & 21.7 & 1.9 & 0.09 & & & & & \\
\hline Water buffalo & 80 & 76.3 & 20.39 & 1.37 & 0.07 & & & & & \\
\hline Elk & 22 & 74.38 & 22.95 & 1.45 & 0.06 & & & & & \\
\hline Moose & 35 & 75.55 & 22.24 & 0.74 & 0.03 & & & & & \\
\hline
\end{tabular}

a Significant digits as presented in the original material.

$\mathrm{b}$ L/P ratio: lipid/protein ratio.

c Barrenland caribou.

d Woodland caribou.

e Marchello et al. (1989: 178).

How are meats with varying amounts of protein and fats prepared? Table 5 abstracts ethnographic information on food preparation and this information is summarized in Table 6. Three general patterns are evident. First, meat that is boiled is primarily from species with low lipid/ protein ratios. In addition, the ethnographic accounts made frequent reference to boiling dried meats. Second, both lean and less lean meat may be roasted in ash, coals, or hot sand and for short amounts of time, i.e., from $10 \mathrm{~min}$ to $1 \mathrm{~h}$. Third, pit-roasting is carried out for meat that has a relatively high lipid-to-protein ratio as indicated in Table 4 or as interpreted from comments in the ethnographic accounts. [Similarly, insects with very high organism lipid levels, such as bee papae (lipid/protein ratio, 0.27) and termites (lipid/ protein, 1.22), along with crickets and grasshoppers, are often described as being either pit-processed or parched (Ebeling 1986:101)]. Additionally, some organs and segments of carcasses are especially high in fat. For example, Kuhnlein and colleagues (1994) report fat proportions of 27 and $43 \%$ for beaver tails and feet, respectively; these were also roasted. One possible exception to this last trend is the pit-roasting of analytically lean rabbits and squirrels by the Surprise Valley Paiute (Kelly 1932:93), about which more is said below. 
Table 5. Meat Tissue by Thermal Processing Technique, Organized by Fat Content (See Table 4)

\begin{tabular}{|c|c|c|c|c|c|c|}
\hline \multirow{2}{*}{$\begin{array}{l}\text { Common name } \\
\text { (fat content code) }\end{array}$} & \multicolumn{6}{|c|}{ Thermal processing technique } \\
\hline & Boil & Broil & Spit roast & Coals roast & Pit roast & Group (reference) \\
\hline \multicolumn{7}{|l|}{ Low fat content } \\
\hline Antelope & $\mathrm{X}$ & & & $x$ & $\mathrm{H}$ & S. V. Paiute (Kelly 1932:92) \\
\hline \multirow[t]{3}{*}{ Bison } & $X$ & & & & & Nez Perce (Spinden 1964:207) \\
\hline & $X$ & & $x$ & & Sit & Plains Cree (Mandelbaum 1979:59) \\
\hline & & & & & $x$ & Crow (Linderman 1962:253) \\
\hline \multirow[t]{3}{*}{ Deer } & $\mathrm{X}$ & & & & & Nez Perce (Spinden 1964:207) \\
\hline & & & & & $\mathrm{H}$ & S. V. Paiute (Kelly 1932:92) \\
\hline & & & $X$ & & & Tepehuan (Pennington 1969:130) \\
\hline Elk & $X$ & & & & & Nez Perce (Spinden 1964:207) \\
\hline \multirow[t]{3}{*}{ Rabbit } & & & & $\mathrm{X}$ & & Paiute (Lowie 1924:196-197) \\
\hline & & & & & $x$ & S. V. Paiute (Kelly 1932:93) \\
\hline & $X$ & & & $\mathrm{x}$ & & Tarahumar (Pennington 1963:91) \\
\hline \multirow[t]{2}{*}{ Squirrel } & & & & $\mathrm{x}$ & & O. V. Paiute (Steward 1933:245) \\
\hline & & & & & $\mathrm{X}$ & S. V. Paiute (Kelly 1932:93) \\
\hline \multicolumn{7}{|c|}{ Suspected low fat content } \\
\hline Fawn & $x$ & & & & & Nez Perce (Spinden 1964:207) \\
\hline \multirow{3}{*}{ Mice } & & & & $x$ & & N. Shoshone (Lowie 1909:189) \\
\hline & & & & $x$ & & O. V. Paiute (Steward 1933:255) \\
\hline & & & & S & & Tarahumar (Pennington 1963:92) \\
\hline \multirow{4}{*}{ Rodent } & & & & & $x$ & S. V. Paiute (Kelly 1932:93) \\
\hline & $x$ & & & $x$ & & Tarahumar (Pennington 1963:92) \\
\hline & $x$ & & $x$ & & & Tepehuan (Pennington 1969:125) \\
\hline & & & & $x$ & & Pima (Russell 1908:82) \\
\hline Sheep & $x$ & & & & & Nez Perce (Spinden 1964:207) \\
\hline \multirow{2}{*}{ Shellfish } & $x$ & & & & & Sanpoil, Nespelem (Ray 1932:107) \\
\hline & & & & & St & Nez Perce (Spinden 1964:206) \\
\hline \multicolumn{7}{|l|}{ High fat content } \\
\hline \multirow{3}{*}{ Bear } & & & & & $\mathrm{X}$ & Nez Perce (Spinden 1964:207) \\
\hline & & & & & $X$ & Sanpoil, Nespelem (Ray 1932:106) \\
\hline & $x$ & & & & $x$ & S. V. Paiute (Kelly 1932:92) \\
\hline Raccoon & & & & $\mathrm{X}$ & & S. V. Paiute (Kelly 1932:92) \\
\hline \multicolumn{7}{|c|}{ Suspected high fat content } \\
\hline Badger & & & & & $x$ & S. V. Paiute (Kelly 1932:92) \\
\hline \multirow{3}{*}{ Crickets } & $X$ & & & & & Tarahumar (Pennington 1963:93) \\
\hline & & & & $\mathrm{x}$ & & N. Shoshone (Lowie 1909:188) \\
\hline & & & & & $x$ & S. V. Paiute (Kelly 1932:93) \\
\hline Eel & & & & $\mathrm{X}$ & & Sanpoil, Nespele (Ray 1932:107) \\
\hline Grasshoppers & & & & $X$ & & N. Shoshone (Lowie 1909:188) \\
\hline \multirow[t]{2}{*}{ Groundhog } & & & & $X$ & & O. V. Paiute (Steward 1933:255) \\
\hline & & & & & $\mathrm{x}$ & S. V. Paiute (Kelly 1932:92) \\
\hline \multirow[t]{2}{*}{ Otter } & & & & & $x$ & S. V. Paiute (Kelly 1932:93) \\
\hline & $x$ & & & $\mathrm{X}$ & & Tarahumar (Pennington 1963:93) \\
\hline Pig & & $x$ & & & & Tepehuan (Pennington 1969:128) \\
\hline Porcupine & & & & & $\mathrm{X}$ & S. V. Paiute (Kelly 1932:93) \\
\hline \multirow[t]{2}{*}{ Salmon } & & & $\mathrm{X}$ & & & Sanpoil, Nespelem (Ray 1932:106) \\
\hline & $x$ & $\mathrm{X}$ & & $x$ & & Nez Perce (Spinden 1964:206) \\
\hline Woodchuck & $x$ & & & & & Sanpoil, Nespelem (Ray 1932:107) \\
\hline Unknown fat cont & & & & & & \\
\hline Fish & & & & $x$ & & Tepehuan (Pennington 1969:133-134 \\
\hline Fowl & $x$ & & $x$ & & & Tepehuan (Pennington 1969:114-116 \\
\hline Lizard, snake & & & & $\mathrm{X}$ & & N. Shoshone (Lowie 1909:189) \\
\hline Turtle & & & & $X$ & & Sanpoil, Nespelem (Ray 1932:106) \\
\hline
\end{tabular}

$\mathrm{H}$, heads only; S, singe; Sit, situationally; St, steam. 
Table 6. Summary of Thermal Processing Technique by Tissue Lipid Content

\begin{tabular}{|c|c|c|c|c|c|}
\hline \multirow[b]{2}{*}{ Lipid content } & \multicolumn{5}{|c|}{ Thermal processing technique } \\
\hline & Boil & Broil & Spit roast & Ash/coals roast & Pit roast \\
\hline High & & & & 1 & 3 \\
\hline Suspected high & 4 & 1 & & 7 & $6^{\mathrm{a}}$ \\
\hline Low & 6 & & 2 & 4 & 2 (rabbit, squirrel) \\
\hline Suspected low & 4 & & 1 & 5 & 2 (rodent, shellfish) \\
\hline Unknown & 2 & 1 & 2 & 3 & \\
\hline Total & 16 & 2 & 5 & 20 & 13 \\
\hline
\end{tabular}

a Includes heads, which likely contain fat-rich brains.

These ethnographic results are consistent with our theoretical understanding of food composition and heat treatment. Dried and lean meats are boiled to restore moisture, which will assist the action of digestive enzymes. Fatty meat tissues may be boiled to further lipid hydrolysis and to melt and ex-press tissue lipids that may then be recovered and used for other purposes, e.g., to make pemmican (Reeves 1990). Fatty meats may also be pit-roasted in a moist environment for several different reasons, the primary of which is likely the ease of preparing of a large piece of meat. That is, the fat enables heat to permeate the tissues very rapidly and the protein is thereby quickly denatured. It is not surprising, then, that large aggregations of people and roasts of fatty meats are often associated. Lipid and collagen hydrolysis would also be promoted by such treatments, which would, again, serve to increase the energy density of these tissues.

How do food composition and preparation correlate in plant tissues? Table 7 presents the compositional analysis of various plant foods utilized by North American native populations and summarized by Yanovsky and Kingsbury (1938). These data are used here with a great deal of caution since the techniques and protocols for analyzing and reporting carbohydrates have changed dramatically in reliability and precision over the last 50 years (Southgate 1991). For example, of the 66 plant foods they examined, only 6 were reported as containing inulin. Erythronium grandiflorum was not among these 6, but is mentioned by Turner and colleagues (1990:122) as inulin-bearing. It is unclear if this discrepancy is owed to technological advances in compositional analysis or to differences in the working definitions of starch, fructan, inulin, dietary fiber, and other dietary components, which have also seen a great deal of elaboration over the past 60 years (Southgate 1991). In any event, more recent (and therefore, reliable) detailed analyses of these plant foods are not available and the following analysis makes due with values from Yanovsky and Kingsbury.

Table 8 again presents ethnographically reported food preparation techniques - none, dry, boil, dry bake, moist bake, other - by plant food as organized by major component; this information is distilled in Table 9. (Where question marks occur in Table 8 , meaning that mode of preparation could not be distinguished among two or three techniques, these were accordingly apportioned; hence the fractional values in Table 9.) The few plant foods for which we have both information on composition and process- 


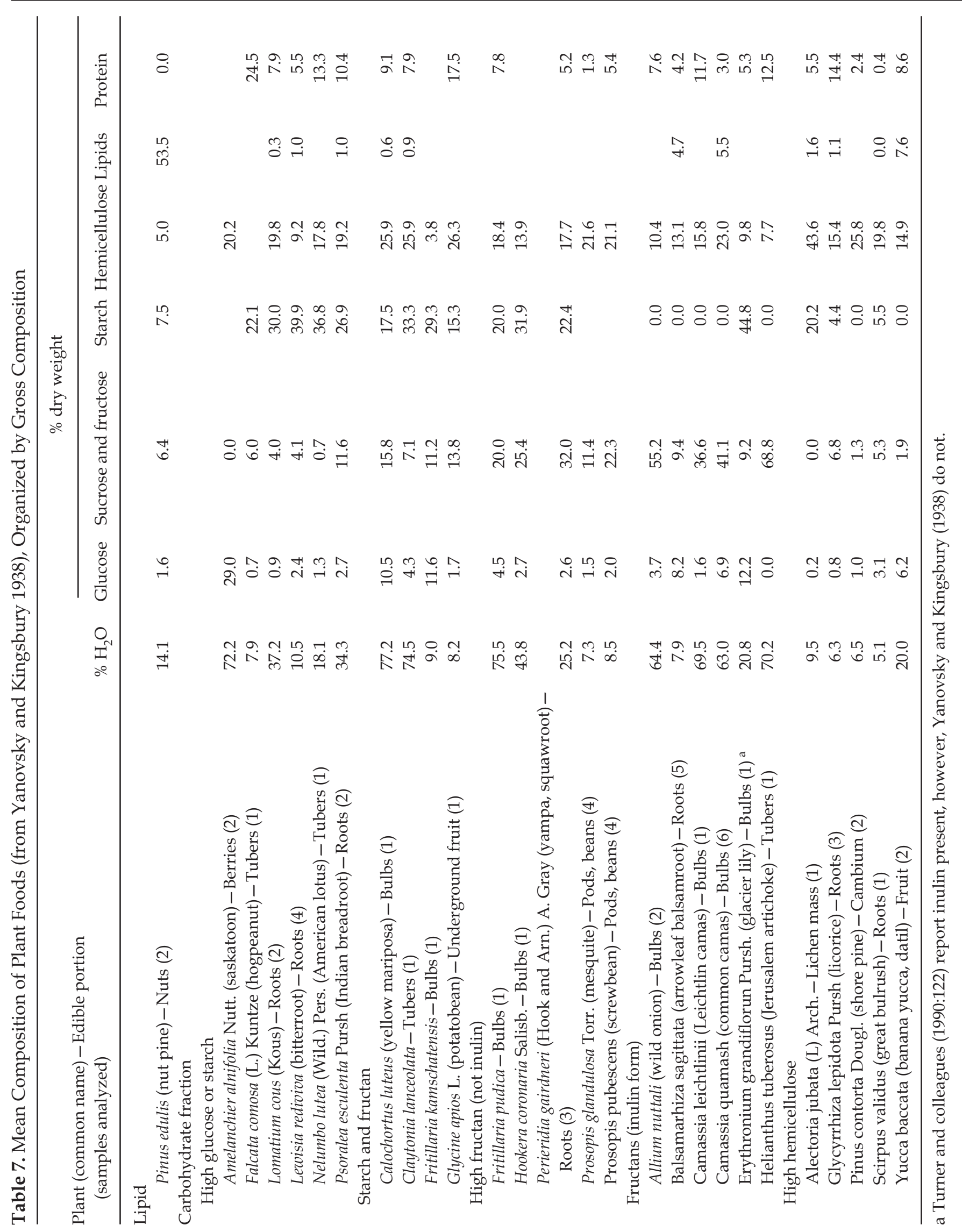


Table 8. Plant Tissue by Thermal Processing Technique, Organized by Major Tissue Component

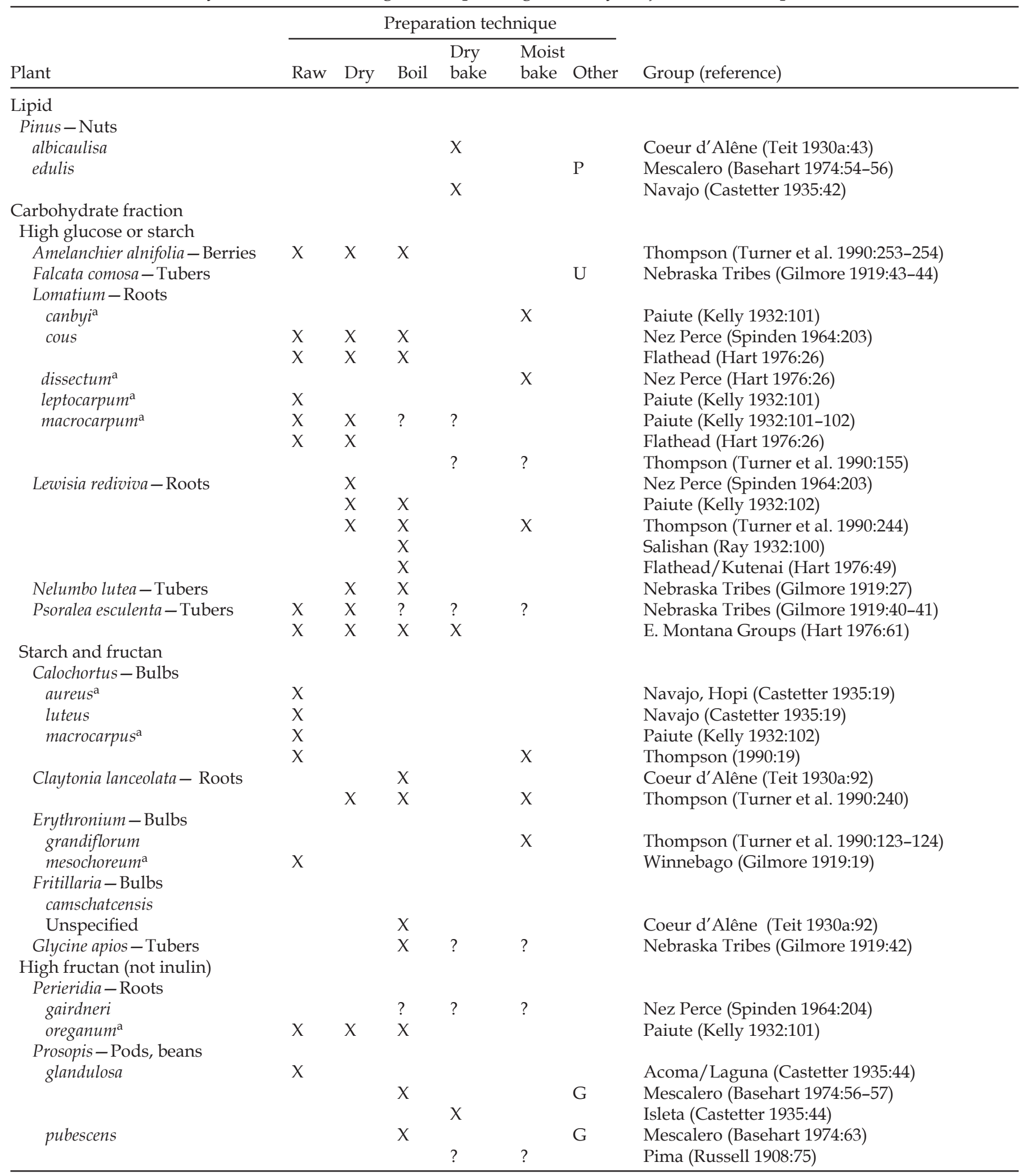

ing means that these results must be considered provocative rather than definitive. They suggest, however, that plant foods rich in starches are primarily boiled prior to consumption, perhaps first being dried for storage. They also point to the occurrence of pit-baking in the case of pine nuts with high lipid content and for foods high in inulin. 
Table 8-Continued

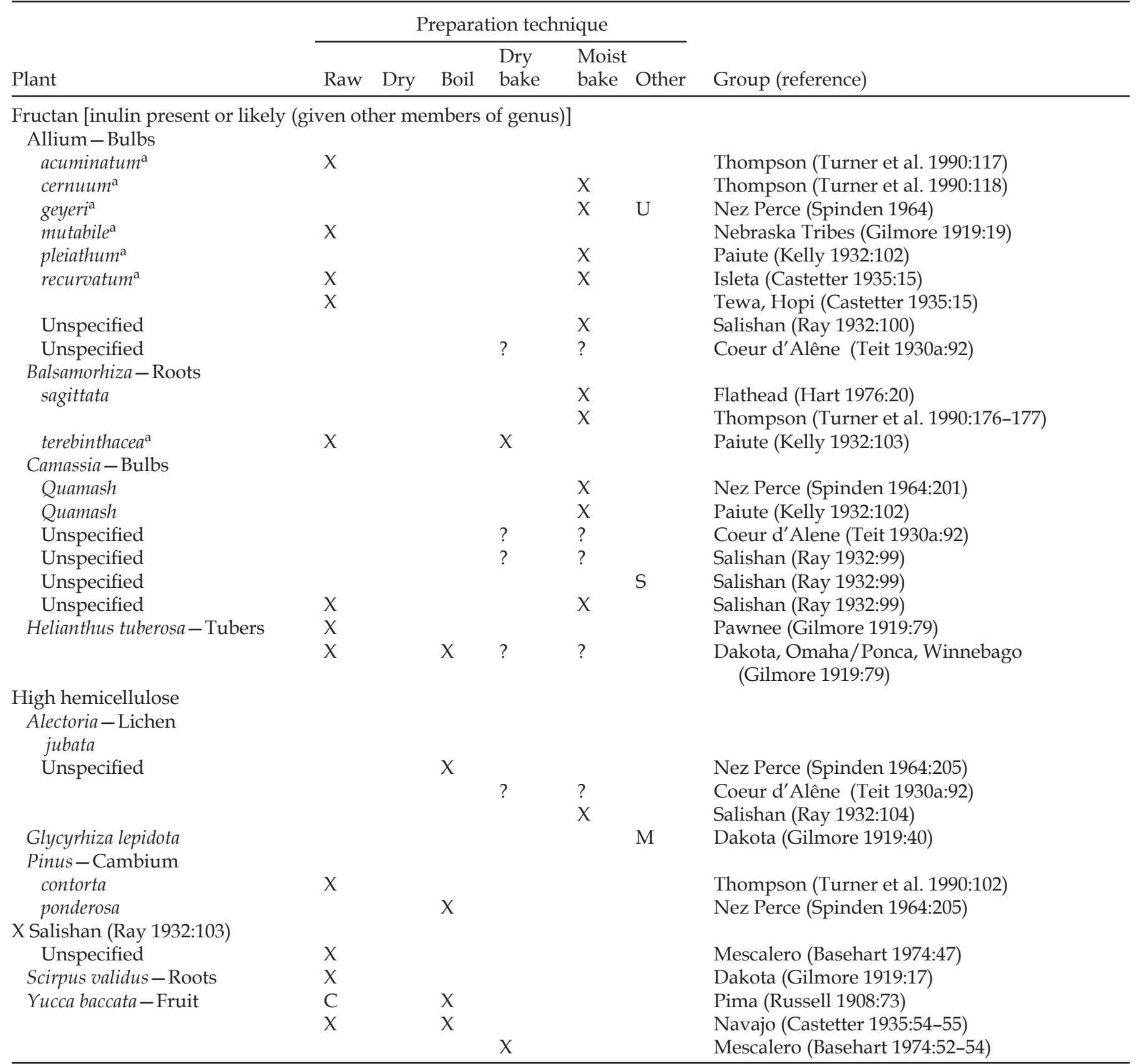

Notes: ? = cooking technique cannot be differentiated; $\mathrm{C}=$ catharitic; $\mathrm{G}=$ grind; $\mathrm{M}=$ medicinal poultice; $\mathrm{P}=$ parch; $\mathrm{S}=$ steam; $\mathrm{U}=$ preparation unspecified.

a Compositional data unavailable.

The different traditional techniques used in the preparation of carbohydrate-rich plant food are not surprising in light of the information assembled above. Foods containing simple sugars require little treatment prior to consumption; to extend their storage life, however, dehydration through either sun-drying or heat treatment provides two appropriate means (and other means, e.g., freeze-drying, adding salt, are available as well). Starchy foods are reported as being dried for storage or boiled. In this latter case, starch gelatinization and pasting are likely being promoted. Foods containing fructan are processed in a variety of ways. It is likely that the mode of processing depends on the structure and degree of polymerization of the fructan. For example, 
onion (Allium sp.; DP 3 -?) might be eaten raw (e.g., Nebraska tribes; Gilmore 1919:19), yacon tubers (DP 3-10) sun-dried first (Zardini 1991), and mesquite bean pods (unknown DP) sometimes pit-baked (e.g., Pima; Russell 1908:75) and other times pounded into flour (e.g., Shoshone and Southern Paiute; Fowler 1995:102).

Finally, inulin-rich foods were reported as eaten raw or pit-baked. Raw consumption of inulin-rich foods may have been undertaken seasonally, when the degree of polymerization had decreased because of frost (Fontana et al. 1993:252). For example, the Thompson Indians of British Columbia preferred to consume the corms of E. grandiflorum (glacier lily) after they had been in cold storage for a while, when they would become sweet like candy (Turner et al. 1990:123). Raw consumption might also promote good health by enabling the activities of bifidobacteria residing in the colon. Pit-baking of inulin-rich foods would have resulted in up to a $100 \%$ increase in the energy obtained from these foods. It also would have denatured some of the secondary compounds that might otherwise have caused ill effects. The final processing of inulin-rich foods often involved shaping the product into loaves or mats that were further dried, either in the pit hearth or by the sun, for storage (e.g., Fowler 1995; Whiting 1985; Malouf 1979; Thoms 1989). Thus, pit hearths also served as dehydraters, in the final phase of processing inulinderived fructose cakes.

From the understanding of food chemistry and human digestive physiology abstracted above, we expect that certain kinds of food will be boiled, dried, baked, or roasted, if people, knowingly or not, are attempting to maximize energy density, minimize disease possibilities, and extend food storage life. Ethnographically documented food processing appears generally consistent with these goals. There is by no means, however, total conformity between expected and observed. Several reasons might be given for this state, including the fact that the ethnographers were "normalizing" what was in fact a fairly situational proceeding; unfortunately, we rarely have the full details for each cooking event. As well, some groups, such as the Havasupai, the Thompson Indians, and the Paiute, seem to pit-roast almost everything. For these groups, it is unclear the degree to which a mobile lifestyle and a lack of large, portable containers is a confounding factor in this analysis. As well, fuel availability and conservation may be an issue with some groups, but not others. In the next section, I attempt to deal with some of these shortcomings by looking at pit-hearth cooking in a more detailed fashion.

\section{Pit-Hearth Food Processing}

All of this information on tissue composition and thermal alteration suggests that cooking strategies should be applied selectively and that a specialized heat treatment, like that of pitroasting or baking, should be employed in very specific circumstances. To further define these circumstances, a more detailed analysis of ethnographic accounts of pit-hearth cooking is considered here. A sample of 110 ethnographic accounts, derived from the Human Resources Area File and other sources, is abstracted in Appendixes $1-3$. This compilation is hardly exhaustive and may overrepresent some applications of pithearth cooking to an unknown degree. For example, camas and other root preparation in northwestern North America is emphasized, as is the preparation of agave, sotol, and cholla buds in the American Southwest. From the western Pacific come various descriptions of pit-hearth processing of a wide variety of foods, including taro, sweet potato, pig flanks, packets of fish, and other vegetable foods. Because of the likelihood of bias in these data, graphs and figures, rather than confirmatory statistics, are used to explore these patterns.

Figure 3 summarizes the incidence of pithearth cooking accounts according to known and suspected food composition. These pie charts reaffirm some of the trends identified earlier, namely, that fatty meats and inulin-bearing plant foods were often pit-roasted. The charac- 
Table 9. Summary of Thermal Processing Techniques by Plant Tissue Composition

\begin{tabular}{llllccc}
\hline Food content & Raw & Dry & Boil & Dry bake & Moist bake & Other \\
\hline $\begin{array}{l}\text { High lipid } \\
\text { Carbohydrate fractions }\end{array}$ & & & & 1 & & 1 \\
$\quad$ High glucose or starch & 5 & 9 & 9.3 & 1.3 & 1.3 & 1 \\
Starch/fructan & 3 & 1 & 4 & .5 & 2.5 & .8 \\
High fructan (not inulin) & 1 & & 2.3 & 1.8 & 8 & 1 \\
High fructan (inulin) & 3 & & 1 & 2 & 1.5 & 1 \\
Hemicellulose & 5 & 4 & 1.5 & & \\
\hline
\end{tabular}

Only foods for which species level information on composition is known are summarized here. That is, plant foods marked with footnote a in Table 7 are not represented here.

teristics of these and other pit-roasted foods are examined in the following.

\section{Protein Denaturation and Lipid Hydrolysis}

[Plenty-coups reflected on his youth:] 'My mouth waters when I remember the meat-holes," he said. "We used to dig a hole in the ground about as deep as my waist. You have seen many of them along the creeks and rivers. We would heat little boulders until they were nearly white and cover the bottom of the hole with these stones. Then we would cut many green boughs of the chokecherry trees and cover the hot stones a foot deep with them. Upon these we would place thick chunks of buffalo meat, fat and fresh from the plains, sprinkling them with water. On top of the meat went another layer of boughs, then more meat, more water, and so on, until the hole was full. Finally we spread the animal's paunch over the hole, covered it all with its hide, put gravel on this, and kindled a $\log$ fire. Men kept the fire going all day and all night yet never burned the robe. The next morning when we opened the hole to feast, even

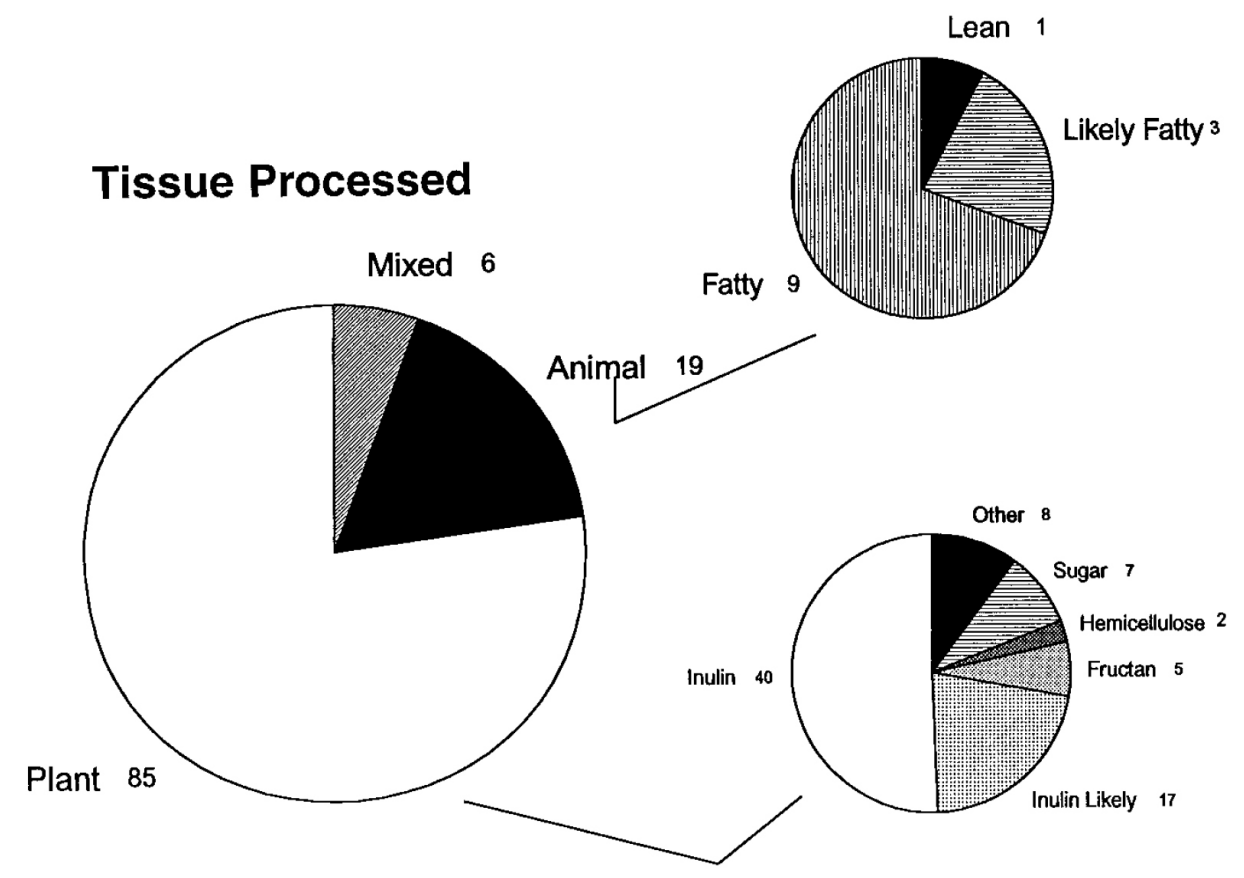

Figure 3. Frequency of ethnographic accounts of pit hearth cooking according to composition of prepared product. (Tissues with unknown compositions are not included.) 


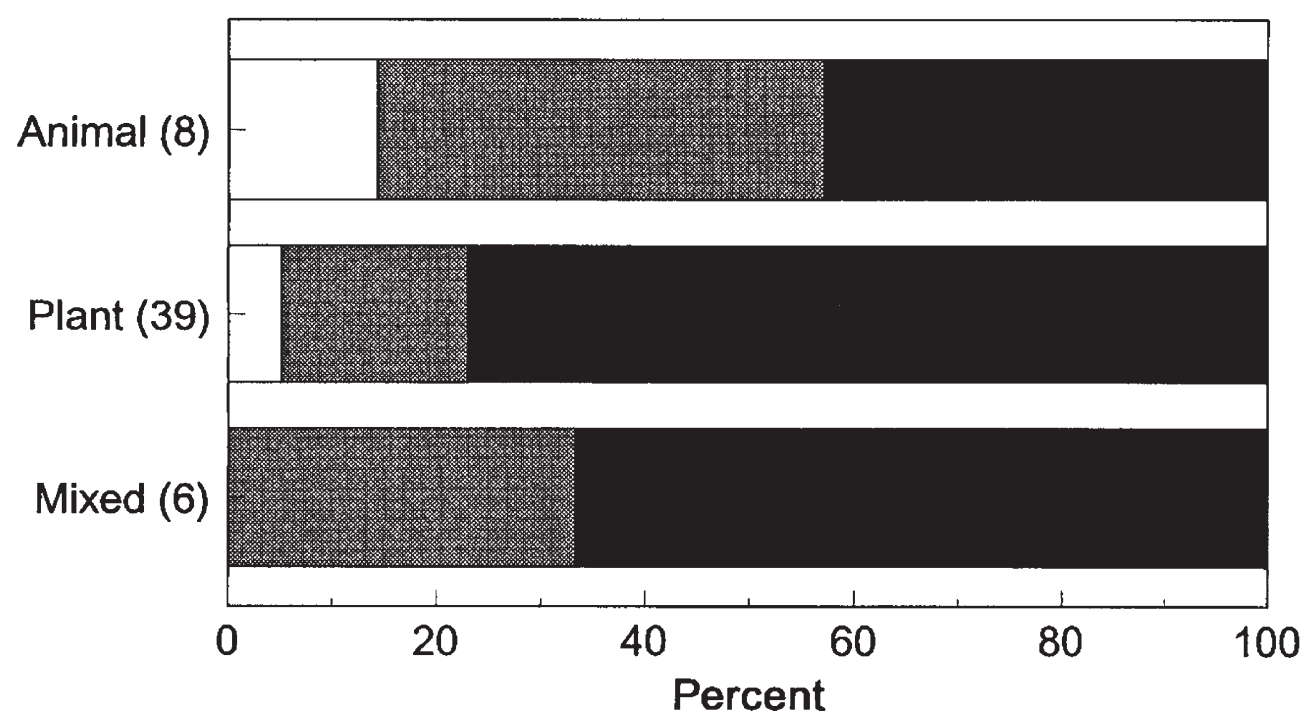

\section{Small Medium $\mathbf{D}$ Large}

Figure 4. Quantities of pit-processed foods. Small refers to individual portions, medium to portions consumable by several families or for several family meals, and large to quantities larger than that immediately consumable by several families.

the birds of the plains were made hungry by the smell of the cooked meat. ... I have made myself hungry telling you this. I will talk of something else to forget meat-holes.' (Linderman 1962:253)

In this account, Plenty-coups is describing the thermal alteration of bison muscle. Plentycoups emphasized the high fat content of the meat and the delicious flavor of the cooked meat. While bison meat is not noted for its high fat content (Table 4), groups appear to have seasonally and situationally targeted specific bison when they were carrying relatively high fat reserves (Driver 1990; Speth 1983). Adding water to the meat as well as sealing the cooking environment so as to prevent the escape of tissue water indicates a moist heat cooking regime. The lengthy cooking time suggests that heat treatment was carried out to promote collagen hydrolysis and lipid hydrolysis undoubtedly occurred as well. And, some degree of fat rendering likely occurred since in many accounts of pig pit-roasting, the plant insulating material was removed from the pit and the fat drippings sucked from it (Dwyer 1990:132).
In the other 18 accounts of pit-hearth cooking of meat listed in Appendix 1, this pattern of fatty meat preparation is supported and two other patterns are readily apparent. First, medium to large packages of meat-a bear, a bison, a python, the heads of large game animals, and multiple lizards, doves, rabbits, or other small mammals-are prepared this way (Figure 4). Thus, the pit-roasting of meat appears to be a means for processing in bulk medium to large quantities of meat.

Second, the heat-time profile of the roasting pit is one likely characterized initially by moderately hot temperatures that rapidly decline and a comparatively short cooking time. As indicated in Figure 5, a rock element was used to store and release heat in only $37 \%$ of the 14 cases for which such information is available. Bear and Plentycoups' (above) bison were prepared making use of a rock heating element and the Havasupai (Whiting 1985:62-63) inserted a heated stone in the abdominal cavity of larger animals during roasting. In most other cases, however, the sediment in which the pit was constructed served as the heat reservoir. 


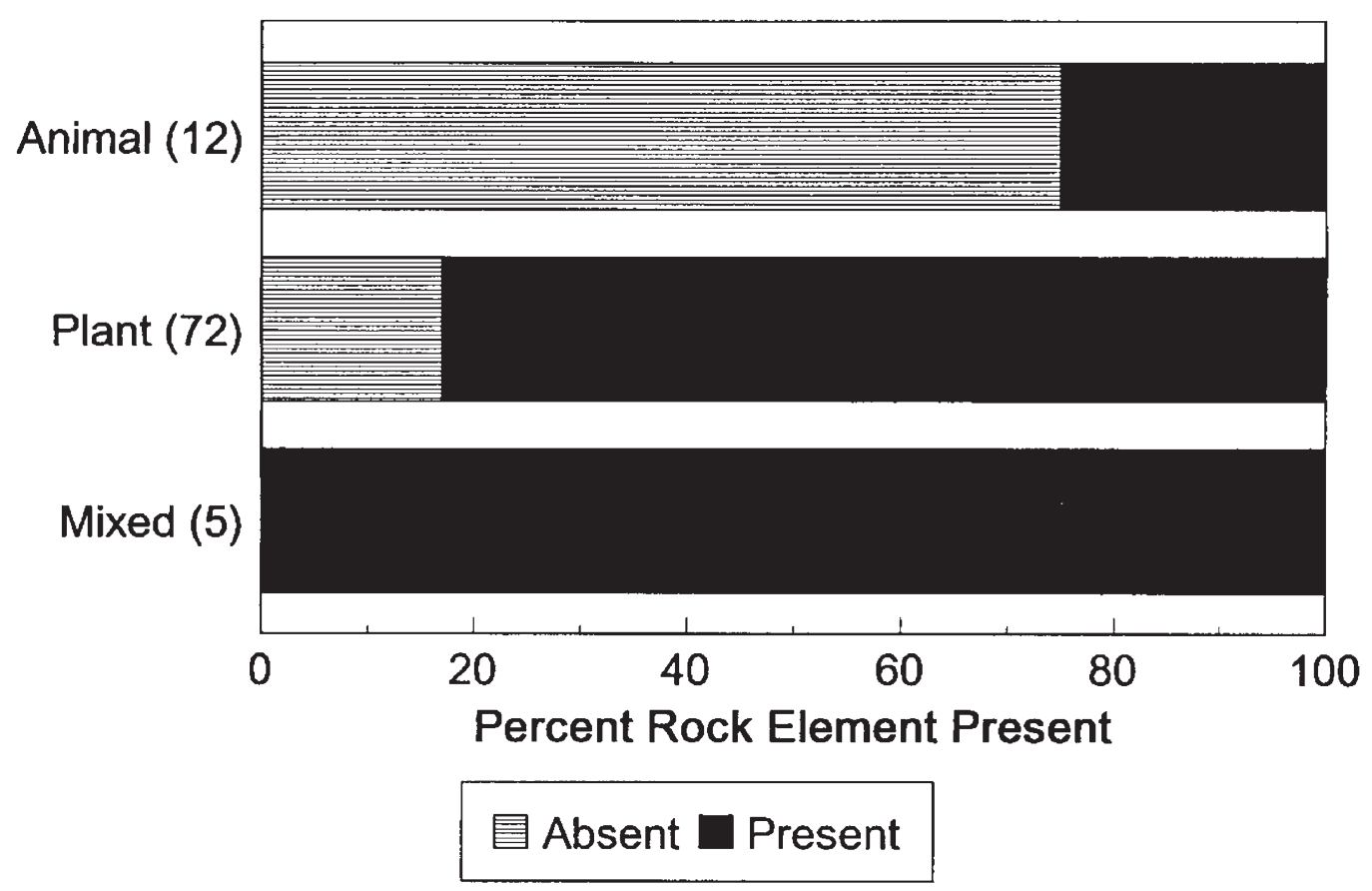

Figure 5. Rock element presence/absence.

Finally, as Figure 6a shows, cooking times of 10 min (for lizards) to perhaps $20 \mathrm{~h}$ (Plenty-coups' account of bison roasting; see above) are reported for pit-processing of meat, with most cooking times being around 2-4 h. Certainly, the amount of food being processed determined to some extent the overall cooking time. As indicated in the preceding sections, however, protein requires only limited exposure to moderate temperatures to enhance its energy and nutrient value.

In sum, fatty meats were often, but not exclusively pit-processed. These data suggest that traditional cooks were making use of the heat transfer property of fat in perennially or seasonally fatty meats to rapidly, evenly, and flavorfully prepare large quantities of meat. Such processing might be useful in either of two situations: (1) when presented with a large quantity of fatty meat or (2) when hosting a feast in which large numbers of people are to be fed.

Two other effects follow from preparing meat in this fashion. For one, the fatty acid chain length is reduced through lipid hydrolysis, producing fatty polymers that are more readily digestible. This extrasomatic hydrolysis might be especially critical to people who only sporadically consumed fat- rich foods. Second, the expressed fat drippings, which were sucked from insulating material by some (perhaps underprovisioned or disenfranchised) people, might allow for the wider distribution of valuable fat in a generally fat-poor environment. It is likely that some fat was lost in this way and so it is not impossible that the pit-roasting of fatty meat tissues may represent a somewhat ostentatious display of fat wastage, a proposition that I cannot presently evaluate.

\section{Inulin Hydrolysis}

[From his notes on life in Polynesia, Rev. William Wyatt Gill wrote:] ... On a given day great logs of firewood and firestones were collected. Next morning an enormous hole or oven was dug. All being ready, on the third day a great crowd of men, women, and children came bearing great uncooked $t i$ roots. The firewood was at a given signal carefully piled up so as completely to fill the hollow; and on the top enormous stones of black basalt were laid, so as to cover the whole. The wood was now lighted in different places, and speedily the whole was in a fierce blaze. When the wood (more than half of which was green) was burnt out, the firestone, now red-hot, sank to the centre of the deep hollow. Now was the moment of danger, when 

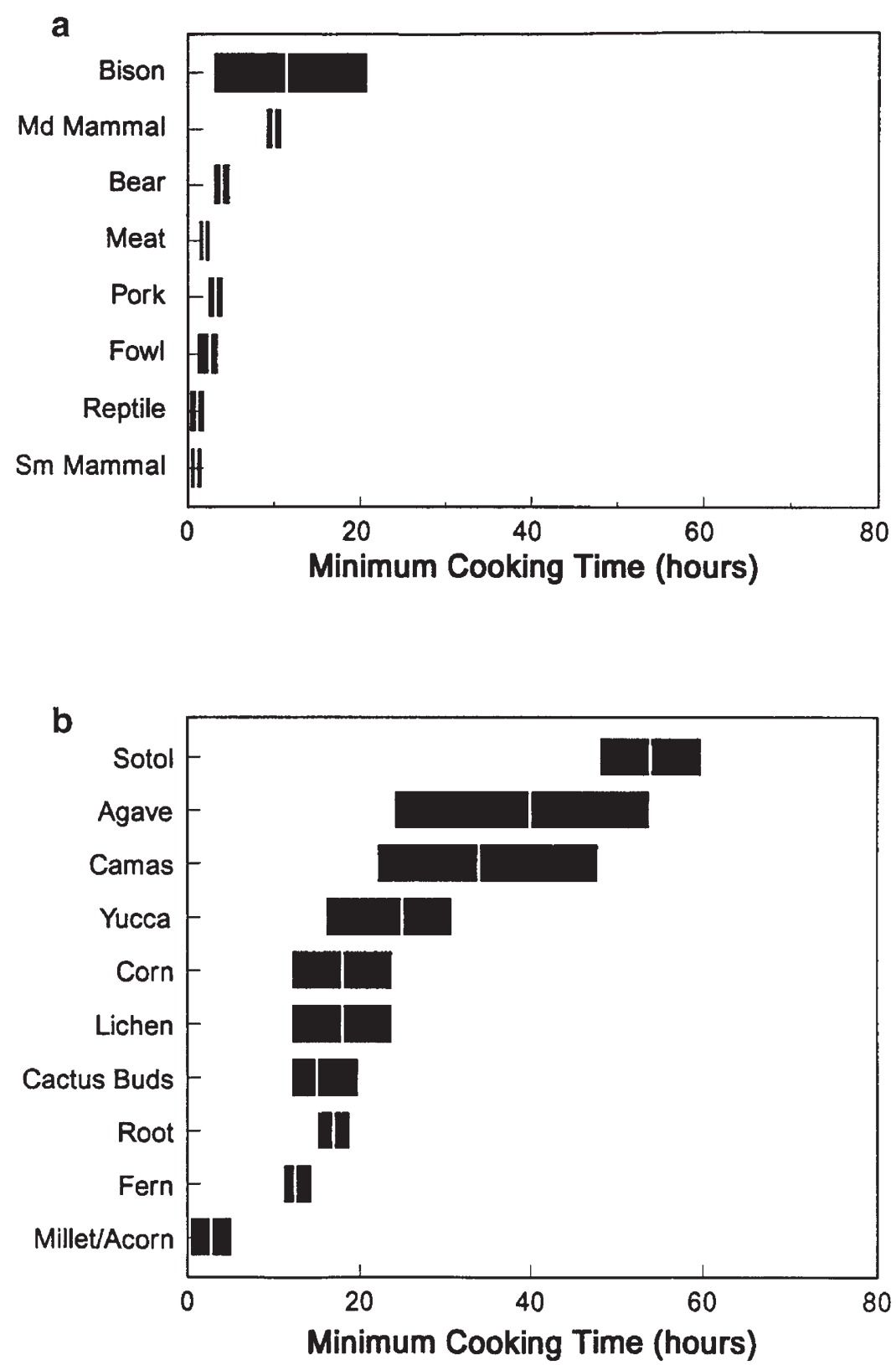

Figure 6. Ethnographically reported minimum cooking times for (a) meat and (b) plant tissues. Bars represent the interquartile range and the median values.

the bravest and most adept selected long green branches of the chestnut with a hook at the end in order to pull these heated stones into proper order, so as to form, in fact, a red-hot pavement, on which the ti roots might be thoroughly and equally baked. This dangerous feat accomplished, laminae stripped off banana stalks with abundance of the juiciest leaves were thickly strewed over these glowing stones. Green limbs of trees were then laid over the oven, to enable men carefully to pack the roots without burning their feet. As the oven was filled with $t i$, these sticks were gradually withdrawn.

In packing these roots the least valuable part is placed downwards, the slender juicy tops upwards. Each person ties something on his own half-dozen or more big roots, so that there may be no confusion when the oven is opened. The roots require to be packed closely, to prevent heat from 
escaping upwards. When the oven is at last completely filled up with ti, the biggest roots being in the centre, the whole is covered over with a vast quantity of leaves. Finally the oven is covered in with earth to the depth of three feet. A large oven requires two whole days and nights for the contents to get thoroughly done. Upon opening the oven, each person is careful to take only his bundle of $t i$ roots . . (Gill 1880:28-29; emphasis in original)

Gill's very graphic account tells of the mass preparation of Cordyline terminalis (palm lily) tubers. ${ }^{2}$ Palm lily tubers contain fructan with a degree of polymerization of 15 and a branched structure (Table 1). The long cooking time and the hot stone pavement (suggesting high temperatures) are consistent with the effective hydrolysis of inulin to fructose and glucose. As Gill (1880:28) noted, "[Processed $t$ ] i is remarkably sweet and agreeable to the European palate."

In other ethnographic accounts, it is clear that people are promoting this hydrolysis by changing the $\mathrm{pH}$ value and moisture content of the cooking environment. For example, the Pima and Tohono O'odham made use of chuchk onk (seepweed, inkweed; Suaeda sp.), which translates as "black salt," to line the pit in which cholla buds were roasted (Curtin 1949:58 in Bohrer et al. 1969:8; Greenhouse et al. 1981:229; Thackery and Leding 1929:414). And, in about 50\% of the 24 accounts of camas roasting, water was added during heat treatment.

Of the 85 accounts of plant foods listed in Appendix 2, the majority of them involve the plants listed in Table 1, all of which contain some amount of fructan or inulin. In a 1983 article on native food use by North American Northwest Coast Native Americans, Turner and Kuhnlein (1983:214) highlighted the significance of pitprocessing to the use of camas: ". . . it would be fair to state that without cooking - and probably without pit-cooking-camas could not have attained the importance it did in native diets." The data presented here suggest that this statement can be generalized to refer to an almost essential relationship between pit-processing and all fructan-bearing plant parts with high DP and/or an inulin or branched structure. That is, plants with these characteristics were, when processed in any moderate to large quantity, always prepared in a pit hearth. (As discussed below, however, pit hearths were also used to prepare millet pancakes and nuts.)

In general, large quantities of plant foods (Figure 4) were prepared this way, at least around and just after the time of contact. For example, Spinden (1964:201-202) reports that 30-40 bushels of camas were prepared at a time, Apache groups prepared "a ton of [mescal] tubers" (Reagan 1930:293), and Pima families processed "several large baskets, dishpans, and tubs" of cholla buds (Thackery and Leding 1929:414). Several factors are likely responsible for this mass food preparation. While many of these plants could be utilized at any time, the time during which the maximum amount of energy could be harvested from the plant is just before that energy is directed to reproduction. Camas was exploited just after flowering (Hart 1976:16); agave, just prior to its flowering. Moreover, the plant part must be processed soon after harvesting, else spoilage occurs (Turner and Kuhnlein 1983:214). The window of maximum opportunity for harvesting camas or agave or other similar plants at any one locale, thus, was likely on the order of several weeks. Groups that especially depended on camas and agave, for example, kept a close watch on those plants and the harvesting and processing of the plant parts was under the strict direction of a specialist [usually female (Reeve 1986), in the case of camas, and either male or female (Fowler 1995:106), in the case of agave]. Isabel Kelly observed southern Great Basin families harvesting agave hearts at increasing elevations throughout the spring as agaves in turn sent up their flower stalks (Fowler 1995:105). Mass processing, then, may be a response to the narrow small window of availability and the short amount of time allowable between harvesting and spoilage. 
In addition to a narrow temporal window, the laborious and resource-demanding nature of the processing itself presumably played a role in decisions about the quantities to process. Heat treating even a small portion of many of the inulin-bearing foods apparently requires an extended exposure to high temperatures. Similar to that described by Gill for ti, very long cooking times are ethnographically documented for the treatment of camas, sotol, agave, and other plants (Figure 6b). The length of cooking time likely has to do with the length of the fructan polymer and possibly also its structure. Low DP plants were apparently processed for short periods, while plants with higher DP values were processed for longer times. For some, like yacon (DP 3), the tubers were only exposed to the sun (Zardini 1991), while Jerusalem artichokes (DP 20) were sometimes boiled and other times pit-processed. On the other hand, structure may be more important. In ti and agave, with DP values of 15 and 32 , respectively, their branched structure may require more energy for depolymerization and hydrolysis to occur.

To achieve a moderate to high temperature over an extended period, people commonly relied upon a rock or stone heat reservoir (Figure 5) and a top fire was sometimes built. Indeed, in 61 of 72 reports of pit-processing of known inulin-bearing foods, the presence of a rock element was mentioned; a majority of the accounts of camas processing report a fire being built over the sealed oven, especially at night. Several accounts (e.g., Tarahumara; Bye et al. 1975:86-89 in Parsons and Parsons 1990:279) indicate that the food product would be tested to see if it had cooked enough. If more time was required, the oven might be disassembled and then reassembled with a renewed heat source.

Given this minimum required level of effort, people undoubtedly realized an economy of scale by processing as much food product at any one time as possible, at least in the latter part of the prehistoric sequence (see discussion below of historical trends). Many accounts note that the size of the pit and heating element was readily expanded in plan (rather than in depth) to accommodate the amount of product. Older (more hydrolysis-resistant) roots were placed in the center where oven temperatures were the highest, as Gill mentions above.

An additional comment on processing time is important here. The pit-processing times given in Figure $6 \mathrm{~b}$ include heating to promote dehydration as well as hydrolysis. Detailed accounts of agave, camas, and sotol processing speak of baking the product for several days, removing it from the pit, and kneading the hydrolyzed product into cakes or loaves. These were either sun-dried or further baked, to reduce water content (and its availability to microorganisms) and, therefore, the possibility of spoilage. The final product, whether camas or agave, had the consistency of plug tobacco, was easy to transport, and preserved well if kept dry. David Thompson wrote about his companion, Lord Metcalfe, who found two camas loaves that were 36 years old to be well preserved, although not as tasty as fresh camas (Hart 1976:17). Similarly, David Prescott Barrows found an agave stalk edible 60 years after it had been harvested and dried (Bean and Saubel 1972:34).

In sum, pit-hearth processing of plant tissues is predominantly associated with mass processing of inulin-rich plant parts. By harvesting and pit-processing such foods, people were able to take advantage of an intensifiable and storable energy source that thrived in areas with few other intensifiable resources. Indeed, Thoms (1989) emphasizes the degree to which camas fields were managed and exploited in the American Northwest and, in the American Southwest, Fish and colleagues (1990) have documented extensive mulch fields that apparently supported agave, perhaps for both food and fiber. 
Starch Hydrolysis and Meat Protein Denaturation

... Women and one older man from Namosado prepared family dishes. They took previously prepared banana leaves, folded at the midrib and often warmed on the oven, and used these to wrap up a mix of greens, meat and fat of pig, and crumbled sago. Watercress, hibiscus, acanth spinach, or pumpkin tips were chosen by different women as their preferred green.

As women completed their packages of food, the men and youths turned to the fire. The wood had burned away, and the stones were hot. Some had exploded, but none had hurtled dangerously from the fire. Using long poles and giant wooden tongs the men rearranged the stones, working rapidly to retain the heat; and when the stones were ready - or even sooner - they were buried beneath fern fronds; and the ten sides of pork, interspersed with pumpkins, chokos, and a dozen or more game mammals, were laid on top and smothered under more fern. No tubers were included. Stones from the edge of the oven were repositioned among the slabs of pork. People called to the others who they thought were being slow, jostled through the crowd to the oven, or shouted angrily that someone else had taken the very place they had chosen for a package of food. The heap grew. Water was poured over it; and as stem billowed up, everyone, shouting, laughing, and calling for others to help, threw huge leaves over the food. The steam was contained and the heap buried beneath dirt. It was done. The excitement dissipated, and for two hours the food cooked (Dwyer 1990:131-132).

This description of pit-hearth cooking comes from Dwyer's account of a public feast hosted by one Etolo (Highland Papua New Guinea) community for another. It illustrates the steam cooking of foods with a variety of compositions. In other accounts (see Appendix 3), fish, sweet potatoes, and packets of taro or sego (the latter three being high in starch; FAO 1990) are mentioned. Minimum cooking times of from 1 to 3 $\mathrm{h}$ are given, which are consistent with the heat treatment of both starch-rich foods and meats with varying amounts of fat and connective tissue. Water is sometimes deliberately added; in other accounts, a rainstorm is underway as the oven is prepared. Water would be important in starch degradation as well as in collagen and lipid hydrolysis.

The role of pit-processing of fatty meats has already been addressed above. Pit-processing of starchy foods, however, appears inconsistent with the results of the earlier section reviewing plant food processing in general. The recent analyses of bushfoods alluded to above, however, indicate that not all starchy foods are equally digestible. A variety of sweet potato grown in the Pacific islands is two to four times less digestible than the common potato, both of them having been baked for $1 \mathrm{~h}$ (Thorburn et al. 1987). Similarly, in their analysis of traditional Pima foods, Brand and colleagues (1990) observed a wide range of in vitro starch digestion; corn was the most digestible and mesquite and acorns the least. Thorburn and colleagues (1987:105) suggest that the relative proportions of the two starch fractions, amylose and amylopectin, are responsible for this variation in digestibility, since amylose resists digestion more than amylopectin. Thus, pit-roasting may play an especially significant role in the hydrolysis of some starchy foods.

In addition, most of these accounts refer to the preparation and immediate consumption of a communal meal. That is, large quantities of food are being heat treated and then eaten. The exception to this pattern is the pit oven prepared for Steensberg (1980:197-201) upon his departure. Within individual communities, joint food preparation may be carried out using an earth oven. On Bellona Island in Polynesia, for example, Christiansen (1975:74-75) observed the women of several families collaborating to prepare the evening meal of fish, poultry, taro, sweet potato and other items in an earth oven. He attributed this joint effort to the large investment in labor and time involved in getting fuel and attending to heating the rock element (Christiansen 1975: 75-76).

Pit-processing of mixed foods, thus, appears to be associated with the mass preparation of foods with similar heat and moisture demands. 
Starch-rich foods require limited exposure to moist heat for gelatinization and pasting to occur and a high temperature heat to support dextrinization. As discussed above for fatty meats, limited exposure to moderate heat promotes the heat transfer throughout the meat, resulting in protein denaturation and lipid hydrolysis. For this reason, a rock heating element is always present (Figure 5) when this kind of cooking is carried out. Interestingly, this heating element may have two parts, a lower one, upon which the meat is placed, and, amidst the packets of starchy foods above, other heated rocks will be distributed.

\section{Toxin Oxidation and Enzyme Denaturation}

The accounts highlighted above do not exhaust the full spectrum of ends achieved in pithearth cooking. Two others, toxin oxidation and enzyme denaturation, deserve mention.

As previously mentioned, plants are rich in a variety of allelochemicals or secondary compounds which, if not removed or treated in some way, have direct or indirect deleterious effects on their consumers. Heat treatment is one way to reduce these negative effects and pit-roasting may serve in this capacity. For example, in several ethnographic accounts, acorns and millet were described as being processed into a dough and then baked. Presumably, the intent of this processing was to deactivate the tannic acid found in these foods (Table 10; Jackson 1991:524-525). In each of these accounts, a relatively small amount of food-for an individual or for a family - was prepared for immediate consumption. The minimum cooking times of 4-5 h would likely be sufficient to denature the responsible protein-based compound.

Generally, the secondary compounds in many roots and bulbs resist degradation by heat treatment and people must resort to other means of detoxification (Johns 1989: 505). While many of the species in Table 10 were identified elsewhere as being pit-processed, only onion was mentioned specifically by traditional peoples as being pit-processed to remove bitterness (Johns and Kubo 1988). In the case of other roots (e.g., Balsamorrhiza sp.), toxins were removed by mechanically peeling the toxic outer skin. The lichen that was pit-roasted by northwestern North American groups was first extensively washed and pounded to express the vulpinic acid it contains (Turner et al. 1990:72). For other plant genera with toxin-bearing members, specific nontoxic species were targeted. For example, the leaves of many agave species contain steroid saponins, and terpenes, as well as vitamins (Table 10; Gentry 1982:21). Throughout northern Mexico and the American Southwest, notes Gentry (1982:6), agave species that are unpalatable because of their high saponin content were avoided as food and beverage sources. The Apachean groups living in this area focused on a number of agave species in the group Parryanae; these species (A. parryi, A. neomexicana, A. gracilipes, and A. havardiana) show no or little evidence of steroids (Gentry 1982:521 -524).

Pine nuts (with high lipid content) are sometimes mentioned as pit-roasted. Heat treatment has the effect of reducing the bitterness of the nuts of some species (e.g., Pinus albicaulis; Thompson Indians; Turner et al. 1990:101-102) and, as previously mentioned, denaturing the lipases that promote rancidity. The pine nuts produced by different species of pine trees are not all equally rich in fats (Farris 1995), but, especially for those that are, heat treatment should result in an extended storage life. As well, cones were heated to express the nuts.

One final kind of plant food mentioned as pitprocessed is that of green or sweet maize. Stevenson (1915:76) reported that Zuni people excavated a deep (3-3.5 $\mathrm{m}$ ) pit in the corn field, filled it with cedar, and allowed it to burn to coals. Unhusked corn was placed inside and roasted for more than $12 \mathrm{~h}$. In modern ripened corn, starch comprises up to $72 \%$ (Greenwood and Munro 1979b:378) of the kernel by weight. In green corn, 


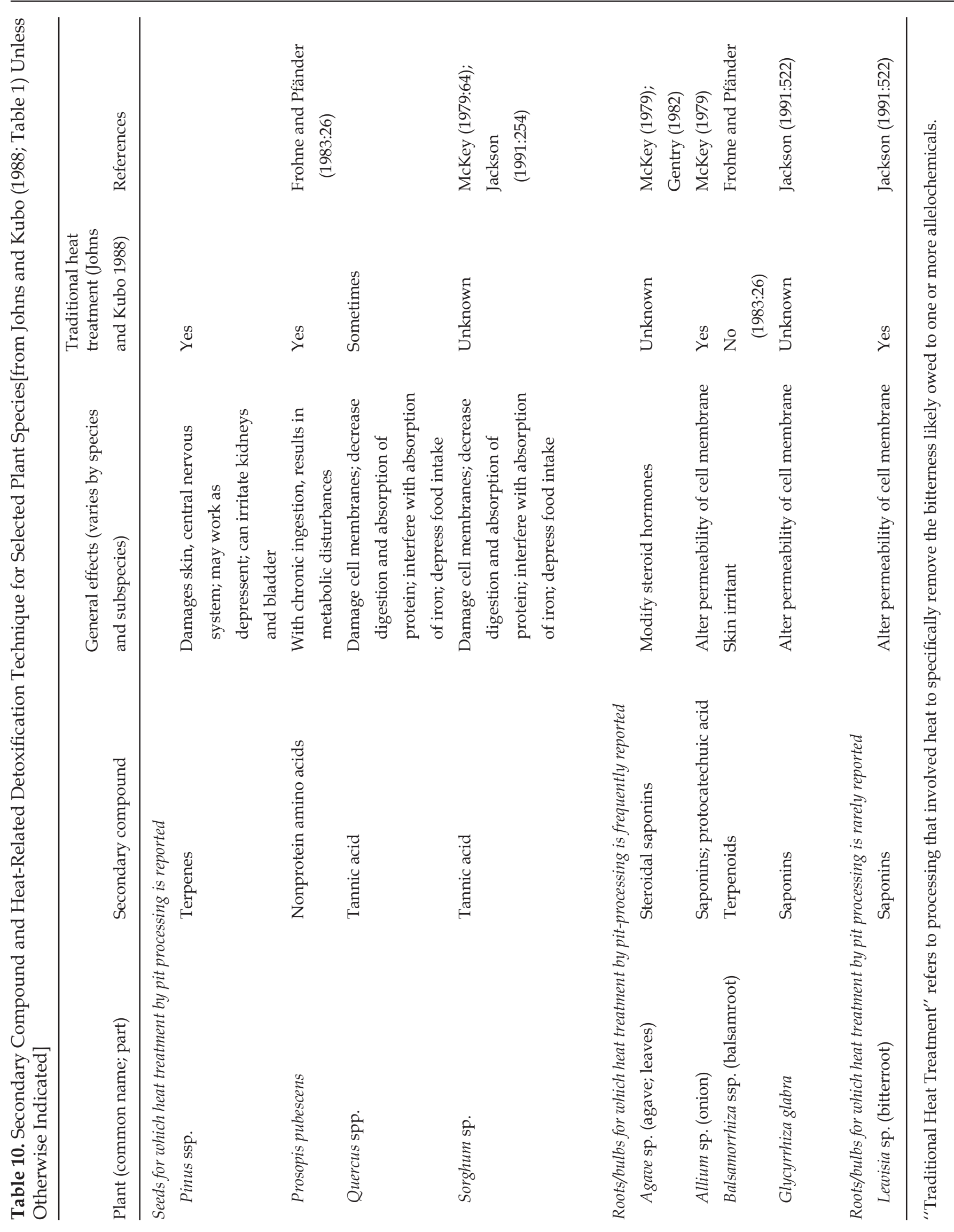


however, much of the kernel, which may be 10$20 \%$ smaller than when ripe, is composed of a sugar. By roasting corn cobs while green, the enzyme responsible for converting the sugar to starch was likely denatured. In this dehydrated, high-sugar state, sweet corn may be preserved for up to 6 months. From the several accounts presented in Appendix 2, it seems that a large quantity of corn, albeit representing a small proportion of the total yield, was prepared this way. As O'Shea (1989:61) notes for the Pawnee, harvesting and processing corn in this preripe state ensured that some of the crop was available for consumption, even if hail or insects devastated the remainder.

\section{Summary}

From this discussion of the relationship between food composition and food preparation, three trends in pit-hearth cooking are clear. First, pit-hearth food processing is associated with those situations in which tissues are cooked for extended periods of time and subjected to moderate to high heat; the moisture regime may vary in these ovens. In the case of inulin-rich foods like camas, agave, and ti, an extended cooking time at moderate to high temperatures appears to be required for inulin hydrolysis to occur (Figure 7). In the case of high-lipid meats, lipid hydrolysis and possibly also collagen hydrolysis are promoted through pit-hearth cooking, with cooking times varying by product amount, but generally being much shorter and at relatively lower temperatures than that observed for inulin-rich foods. In mixed food preparation, foods with similar heat treatment requirements, i.e., fatty meats and hydrolysis-resistant starches, are prepared together at moderate to high temperatures, but for relatively abbreviated cooking times. Pit-hearth cooking with the end of enzyme denaturation or toxin oxidation appears to occur at moderate temperatures for short periods of time. Archaeologically, it should be possible to infer or monitor the temperature achieved in a pit hearth with experimental data on hearth rock heat capacities or modified paleomagnetic techniques (e.g., Takac and Collins 1995). Although crude, the presence/absence of hearth rock also indicates to some extent the length of time over which an elevated oven temperature was maintained. And, it may be possible to experimentally determine heat-time profiles for ovens of varying shapes and containing varying quantities of rocks.

The second trend involves the typically large quantity of food that was pit-processed. In the case of meat or mixed food preparation, several families and sometimes an entire community was fed from the pit hearth. In the case of vegetable tissues, mass quantities of food were almost always prepared for storage although familysized portions of inulin-rich foods were sometimes prepared for immediate consumption (see Del Barco 1973 account in Parsons and Parsons 1990:277 - 278). Pit-processing of doughs and pastes usually involved small quantities. Archaeologically, estimates of pit-hearth volume are approachable and have been used by researchers (e.g., Reeve 1986; Thoms 1989) to monitor the reliance of past peoples on pit-processed foods. It is not necessarily the case, however, that pit size translates exactly to volume of food processed. In preparing yucca hearts, the Kawaiisu would excavate a pit to contain the heating element; the actual cooking structure extended to a height of more than $1 \mathrm{~m}$ above the ground (Zigmond 1981:70).

Finally, also telling is what is NOT being pit-processed, namely, lean meats and plants high in sugars and fast-release starch. In the ethnographic accounts of pit-processing reviewed here, no accounts of lean meats were explicitly noted, although some animals with generally lean tissues are mentioned. In the case of rabbits and squirrels pit-processed by the Surprise Valley Paiute (Kelly 1932), it may be that seasonally fatty animals were processed this way or that the substrate precluded hot sand cooking but permit- 


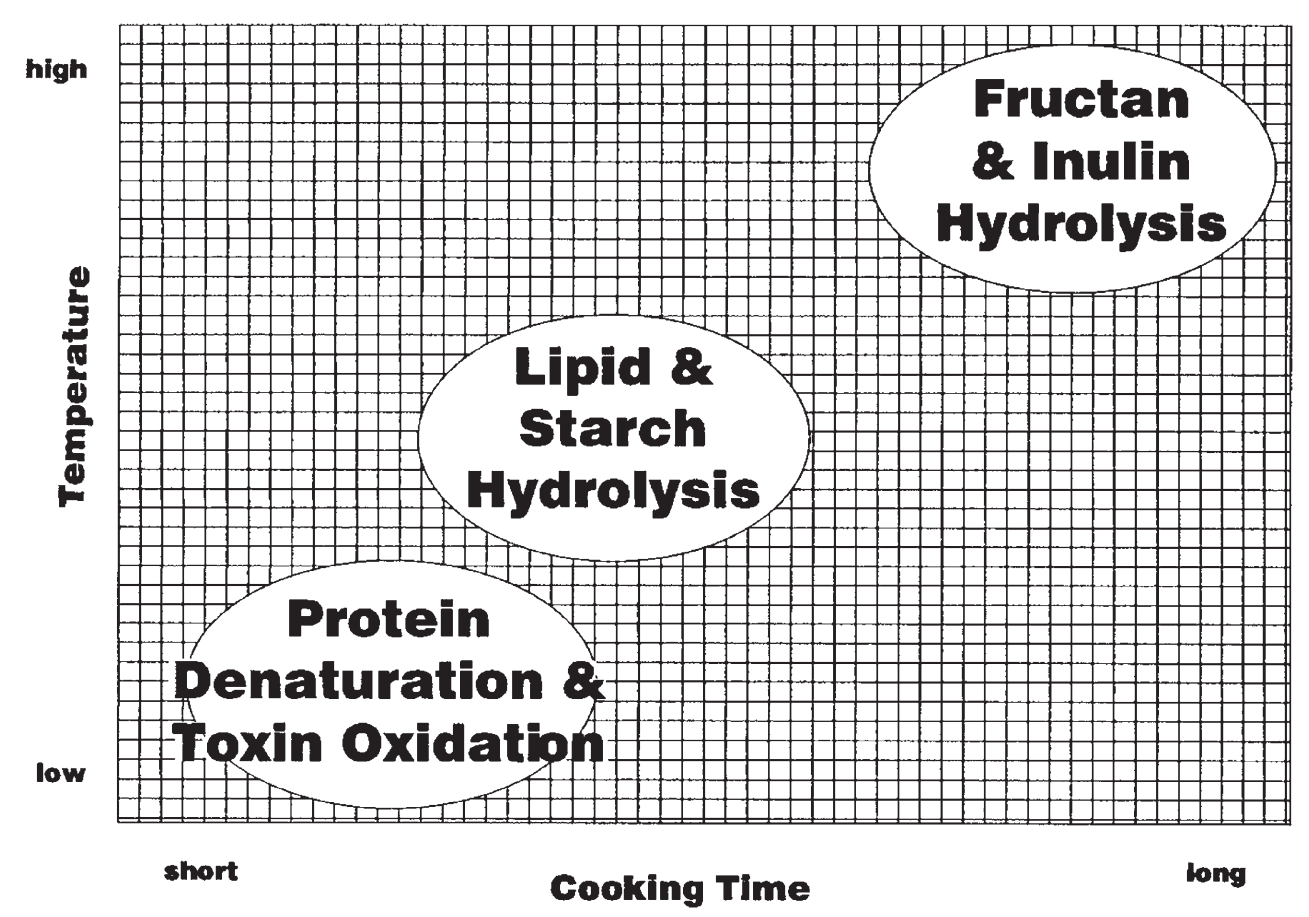

Figure 7. Pit hearth cooking summary by length of cooking time and temperature.

ted pit-hearth cooking. Furthermore, except for sweet corn, plant foods with high sugar content are not mentioned as pit-roasted or baked. And, while some starchy roots and piths like sego were pit-baked, starchy seeds were only mentioned if they had first been mechanically altered through grinding or grating. No whole seeds were mentioned as pit-roasted, but may be roasted in hot sand and then sifted.

\section{Evolutionary Implications and Archaeological Observations}

The relationship between diet and the evolution of human physiology is a perennially important topic of research involving population geneticists, nutritionists, and points is discussed below. other physical anthropologists (Eaton and Konner 1985; Garn and Leonard 1989; Larsen 1995; Stahl 1984; Stinson 1992). The focus here is on the relationship between the precontact diets of many indigenous populations and diabetes mellitus.
Type II diabetes mellitus, i.e., maturity onset non-insulin-dependent diabetes mellitus (NIDDM), occurs at an alarming frequency and with lethal consequences in many indigenous populations today (Stinson 1992; Szathmáry 1994). The above discussion of food composition and pitroasting may help to shed light on the origin and distribution of NIDDM in these populations in at least two ways. It suggests that besides starch, other complex carbohydrates, i.e., those rich in fructan and inulin, be examined for their dietary effects. Second, it suggests that we can use archaeologically visible roasting features, that is, features used in extrasomatically hydrolyzing resistant starches and inulin, to monitor the appearance and relative dependence on these foods. In this way, we may be able to track Neel's $(1962,1982)$ thrifty genotype through time. Each of these points is discussed below.

\section{Evolutionary Implications}

Diabetes mellitus is manifested as abnormally high levels of blood glucose. In individuals with type I diabetes, the pancreas fails to pro- 
duce insulin, which in turn works to promote the uptake of glucose, fatty acids, and amino acids by cells. Death results unless insulin is supplied exogenously, hence the term insulin-dependent diabetes mellitus. In NIDDM or type II diabetes, hyperglycemia is accompanied by excessively high levels of insulin, which leads to a variety of complications. Over time, an individual with this disease may lose the ability to produce insulin and may experience heart disease, kidney failure, blindness, and poor circulation, often resulting in gangrene in injured extremities (and, therefore, amputations) (Szathmáry 1994:457-458).

Over the last several decades, an increasing incidence of NIDDM has been noted for some Native Americans (Gohdes 1986, 1995), Polynesians (Collins et al. 1994), Australian Aborigines (O’Dea 1991), New Guinea groups (Hodge et al. 1996), and others (see Szathmáry 1994:457). As of 1987, half of all adult Pima have been diagnosed with this disease (Gohdes 1995), which usually occurs at a level of around $1-3 \%$ in North American populations of European extraction. The increase in prevalence rates appears to coincide with lifestyle changes that include a reduced level of activity and also diets composed of foods high in fats and processed carbohydrates, and low in fiber.

In 1962, James Neel proposed that NIDDM was one manifestation of a "thrifty genotype," which, under the "feast and famine" conditions he postulated for early hunter-gatherer groups, conferred a selective advantage to its bearers. Such individuals, he suggested, were able to rapidly process and store glucose as fat rather than suffer urinary caloric loss. As groups came to rely on more reliable cultivated cereals, which are high in starch and are processed to glucose, a concomitant change in human physiology occurred. Historic hunter-gatherer or horticultural populations that have only recently been incorporated into the Western economy are suffering, he suggests, the telescoped effects of an evolutionary process that, in populations with a long history of cereal use, happened perhaps over many generations. Now that recently colonized populations have reliable access to abundant fatty foods and processed carbohydrates, the "thrifty genotype" has become detrimental to the health and well-being of its bearers. Much research has been conducted on diabetes since 1962, leading Neel (1982) to revise his understanding of the mechanisms responsible for NIDDM; the fundamental basis for a thrifty genotype remains unaltered.

Other evolutionary scenarios have been offered. Wendorf and Goldfine (1991) suggest that selection for a thrifty genotype would have occurred as ancestral Amerindians attempted to subsist on risky faunal resources south of the glacial ice. A thrifty genotype associated with the ability to reduce hyperglycemia during fasting but allow for energy storage in fat and liver during feasting would be beneficial to members of the hypothesized first and second colonizing populations, but not in the latest or third (when the climate ameliorated). Szathmáry (1994) argues that the high-protein, low-carbohydrate diet of Paleoindian immigrants to North America may have selected for thrifty lipid metabolization and storage. Their descendants, especially those in the northern latitudes who until recently subsisted primarily on meat, now suffer the consequences of glucose intolerance in a carbohydrate-rich environment. While either of these explanations might explain some of the observed variation in diabetes rates seen in Native American populations, neither speaks to the high rates of NIDDM observed in other Westernizing populations.

Already mentioned above, other recent research points to important digestive qualities of traditional foods. Thorburn and colleagues (1987) show, for example, that the starchy bushfoods traditionally used by Pacific Island groups and Australian Aboriginal groups can be classed along with legumes as slow-digesting, slow-en- 
ergy-release foods, which contrasts with fastrelease Western carbohydrate foods. They relate this slow-release quality to the nature of the dominant starch fraction, amylose, which resists digestion to a much greater degree. Similar results were reported by Brand and colleagues (1990) for six staple foods of the Pima. Again, beans, mesquite, acorns, and even native Zea mays, each of them traditionally prepared, showed slow-release profiles compared with the control of wheat bread. In both studies, the authors suggest that the thrifty genotype, which is manifested today in complications attributable to NIDDM, may have evolved in circumstances which hydrolysis-resistant starches comprised major portion of the diet.

To date, evolutionary scenarios describing the appearance of a thrifty genotype have not considered the role of inulin-bearing foods. Such foods, however, comprised large portion of the diet for many groups. In the northwestern portion of North American, for example, camas was a mainstay of many groups (Thoms 1989). In nearby British Columbia, the Thompson Indian informants named E. grandiflorum (glacier lily), an inulin-bearing member of the lily family, as the "boss" root because of its abundance and importance in their diet (Turner et al. 1990:122). Similarly, agave served as a staple food for groups in the southern Great Basin (Fowler 1995). The vast mounds of fire-altered rock found on the southern Plains of North America and usually associated with mescal processing suggest a major reliance on this food (Greer 1965) and at least one account of an individual who lived for some time with Comanche and Apache groups (Eastman 1879:115 -116) testifies to its extensive usage. Agave was widely utilized all throughout northern Mexico (Gentry 1982). For the Pima and Tohono O'odham of southern Arizona (North America), cholla buds, a plant food I classed as likely containing inulin (because of its postprocessed sweet taste), and mesquite pods (fructan-bearing) were relied upon along with corn. For Aborigines in southern Australia, Gott (1983) highlights the importance of murnong (Microseris lanceolata), which served as a staple until recently; when murnong was destroyed by the grazing sheep and rabbits of the colonizing Europeans, the Victorian Aboriginals were forced to seek food from the colonists (Gott 1983:12-13).

In other groups, inulin-rich foods functioned as critical emergency rations. "Hard foods" was the term used by the Mescalero Apache to describe agave, sotol, and yucca. These are "foods that [had] to be baked" and were relied on during droughts (Basehart 1974:60). The Pima and Tohono O'odham similarly used agave in difficult circumstances. Even as recently as 1988, the Mountain Pima living in northern Mexico turned to agave and other wild foods when their crops failed (Laferriere 1992). Gill (1880:22) notes that in Polynesia, ti was used during the winter months when taro was unavailable.

In addition to this documented reliance on inulin-rich foods, we also know that fructose, to which inulin and other varieties of fructans are hydrolyzed (along with a relatively low proportion of glucose moieties), may perform as an alternative energy source for diabetic patients today. Various studies have reported both positive and negative effects accruing to diabetics consuming fructose rather than sucrose (Crapo 1994:423). The fear is that fructose consumption will lead to increased levels of serum lipids, resulting in other diabetic complications. This consequence appears to occur in some susceptible NIDDM individuals, but not in those with mild symptoms.

Thus, it is reasonable to hypothesize, as suggested by O'Dea (1986), that populations with a genotype selected to metabolize hydrolyzed inulin and slow-releasing starches may be ill suited to diets rich in fast-release starches and sugars. If this is the case, then we can outline expectations for the geographic distribution of NIDDM. 
Brand and colleagues (1990) have already suggested that the wild larder of groups residing in arid areas would likely contain legumes and other slow-release complex carbohydrates; groups in these areas ingesting modern Western diets high in simplified sugars may suffer from NIDDM. We can go a step further and hypothesize that in those temperate and semiarid areas where plants store energy as fructan rather than starch, groups harvesting and consuming these bulbs and stalks may have been subjected to a similar selection. The descendants of groups that evolved in these areas, thus, may also be more susceptible to NIDDM.

Several lines of evidence suggest that this proposition is worthy of further research. First, in general, subarctic groups for which high NIDDM incidences (Gohdes 1986, 1995) are commonly reported are those that, at European contact, resided in the western United States, where slow-release starches and inulin-rich foods appear to occur. Of course, other factors, including the differential reporting of NIDDM in Native American populations, degree of dependence on a Western diet, amount of European admixture, and others play a role as well. Similarly, as noted above, high and increasing NIDDM incidence rates are reported for Australian Aboriginal, Polynesian, Micronesian, and New Guinea indigenous populations with a similar historical reliance on complex carbohydrates. Second, when affected or predisposed NIDDM individuals are placed on a traditional diet, their NIDDM symptoms are ameliorated or abate (O'Dea 1991:239). Third, the consumption of inulin by rat and human subjects apparently has beneficial effects on glucose tolerance and serum lipid levels (Gupta et al. 1993; Roberfroid 1993), although the responsible mechanisms are not well understood. Finally, several studies have reported variation in glucose responses within populations (Neel 1982; Omar et al. 1994). These responses may be evolutionary consequences owed to the differential composition of the diets historically enjoyed by differ- ent sub populations within an otherwise apparently homogenous population.

The important point here is that inulin-and fructan-rich foods not only provided a critical and intensifiable energy source (Thoms 1989) but also that the fructose and inulin nature of that energy source itself may be significant. Populations that evolved while dependent on fructan, inulin, and other digestion-resistant foods were subject, it appears, to a selective force that may be in part responsible for the high incidence of NIDDM in indigenous populations around the world today.

\section{Archaeological Observations: \\ Examples from the American Great Plains and Elsewhere}

Archaeologically, we are in a good position to observe the appearance of technologies designed to advance the digestion of hydrolysis-resistant starches and fructans or prepare fatty meats. If the speculation entertained in the preceding section holds any merit, hot-rock and pit-hearth features may inform on the appearance of a thrifty genotype.

On the northwestern Plains of North America, Davis and colleagues (1993) have reported the presence of Paleoindian (9400 BP) roasting pits and hearths at the Barton Gulch site. The roasting pits, which ranged in depth from 26 to $68 \mathrm{~cm}$, contained charcoal and various macrobotanical remains but no rock element. They are found in redundantly occurring arrangements of two to four per central hearth. Their lack of a rock heating element suggests that they were not used to hydrolyze inulin-bearing plants or fatty meats, although they may have been used to process high-lipid seeds, like those of Pinus flexilis (a few seeds of which were recovered) or to dethorn the meats of Opuntia polycantha (the seeds of which are relatively abundant here) (Armstrong 1993:13). Following Greenhouse and colleagues (1981), the other seeds recov- 
ered from these features may represent the natural seed rain that occurred in the area. In addition, numerous bones of deer and rabbits were recovered here and it is not impossible that the pits represent protein denaturing pits. An analysis of burn marks on the bone fragments themselves may be able to inform on this possibility. In any case, slow-release starchy foods, fructanbearing foods, or fatty meats appear not to have been processed at Barton Gulch.

This manifestation is in contrast to that on the southern North American Plains, where Dering (1996) reports charred camas and onion fragments from roasting pits that date to as early as 8000 BP. The presence of likely inulin hydrolysis pits as early as the late Paleoindian period suggests that the coevolution of some Native American populations with these foods was underway by this time.

Elsewhere on the northwestern Plains of North American, Frison (1983) notes the appearance of cylindrical pit hearths with rock elements during the early Archaic (8000 BP). He (1983:89) writes that "the extent of the oxidation rings present in many fire pits argues for a considerable amount of heat and possibly more than can be explained away as needed in simple food preparation." The examination of food composition and processing presented above suggests that foods requiring extended heat treatment, i.e., those rich in inulin or resistant starches, or in fat, were likely prepared here. The location of some of these features in high-altitude meadows, where camas and other bulbs flourished historically (Francis 1995), especially supports the interpretation that these features performed as inulin hydrolysis pits. These pits also, then, signal the appearance of a population that is likely evolving on a diet that contains some amount of fructose.

In the central High Plains south and southeast of the Black Hills, deep cylindrical pit hearths dating to the Late Prehistoric (700-1100 AD) are common occurrences (Falk et al. 1978; Johnson 1996; Meston 1976; Schultz and Smith
1965; Sheldon 1905; Wandsnider et al. 1995). These hearths often contain a rock element, but to date few other remains have been recovered to suggest their function. It is unlikely that these hearths were used to process inulin-rich foods because the rock element, composed of the local sandstone, has a relatively low heat capacity, unlike the basalt cobbles frequently mentioned in ethnographic texts of agave or ti processing. Bone preservation is generally good in this area and the lack of bone here suggests that meat processing was not undertaken. Presently, I hypothesize that an as yet unidentified plant composed of a low DP fructan or a resistant starch was pit-processed in quantities as high as 75 $\mathrm{kg} /$ pit. The presence and high density of these pit hearths suggest that a population bearing the thrifty genotype was in the area as recently as 1000 years ago.

In other parts of the world, we find dramatic archaeological evidence for the exploitation of hydrolysis-resistant resources. Throughout the southern Great Plains, the American Southwest, and northern Mexico, thick and extensive aggregations of fire-cracked rock occur, sometimes in association with definable pits. These features are usually attributed to agave processing and date from the Archaic into Protohistoric times (Gentry 1982; Greer 1965; Abbott and Frederick 1990). The very massive nature of these features testifies to the importance of agave to the people in this area, although whether as a staple or as starvation food remains unclear. As already noted, in this area today, NIDDM is recognized as a major health problem among Native American and Mexican populations (Knowler et al. 1978; Stern et al. 1991).

Throughout northwest North America, archaeological evidence for camas exploitation abounds. In an exceptional study, Thoms (1989) documents the appearance of camas use in interior areas by about $8000 \mathrm{BP}$. Increasing frequencies of roasting ovens suggests an intensification of this resource by around $4000 \mathrm{BP}$ (Thoms 1989:463-464) and camas continued in use as a 
staple until just recently. Again, NIDDM is reported at above average levels in indigenous populations in Oregon and Washington (Freeman et al. 1989).

In northwestern Europe, vast mounds of burned stone have received professional scrutiny for many years (Buckley 1990; Hodder and Barfield 1991; O’Kelly 1953; Ó Drisceoil 1988). As Thoms (1989:476) notes, the geographic distribution of this archaeological phenomenon is consistent with the range of bulbs and roots similar to camas and glacier lily. On the basis of the information assembled here, the dense and extensive burned rock mounds also suggest that a processing strategy applied to a hydrolysis-resistant food, likely containing inulin, was in use. If this is the case, than we may expect to find residual occurrences of NIDDM in north European, north Asian, or other populations that evolved while subsisting on these digestion-resistant foods and have only recently begun to rely on processed starches. Archaeology and medicine may profitably work together to sort out this possibility.

Of import here is that, at least in the New World, the initial use of inulin-rich foods appears to date to the early to middle Holocene. By the mid-late Holocene, more intensified use seems to occur, and Thoms (1989) has argued that other more cost-effective foods would likely have been intensified first, if available. If the dependence on diets with a large carbohydrate fraction coming from inulin and fructose is related to the appearance of the thrifty genotype, then selection for this genotype was perhaps most intensive during the later part of the Holocene. At this time, both historically and ethnographically in North America, we see a relatively high dependence on inulin-rich foods, especially in those areas where cereal agriculture could not be undertaken or could not be depended upon. When other viable crops, such as the potato, are introduced, or the market economy makes flour and other commodities available, the use of both inulin-rich foods and pit hearths plummets.

\section{Conclusion}

Pit hearths are common archaeological features with great potential to inform not only on functional aspects of food processing but also on evolutionary matters. To further our realization of this potential, this paper has attempted to build a body of reference knowledge on the relationship between food composition, food chemistry, and heat treatment.

Ethnographic accounts indicate that inulin-and lipid-rich foods of moderate and large quantities were pit-processed. In addition, hydrolysis-resistant starches appear to have been processed this way, especially in the western Pacific. Pit-hearth cooking is an obvious and efficient way to hydrolyze large amounts of resistant starches and inulin, which require exposing tissues to high temperatures for, in the case of inulin, long periods of time. The thermal pitprocessing of fatty meats appears to take advantage of the heat transfer properties of tissue lipids. In addition, pit hearths were used to reduce toxins in small batches of food and to enhance the durability of foods like sweet corn and pine nuts. Archaeologically, we may be able to use pit-hearth morphology, the nature of the rock element, lipid identification (Evershed 1993), pit contents (Dering 1996; Hather 1991), and other indicators to more specifically diagnose the pit hearth's function.

Other work on the subject of cooking systems and pit-hearth cooking remains to be done. This paper has primarily focused on the cooking function of pit hearths. Yet, we know that pit hearths functioned as kilns, in which ceramic vessels were fired (Blackfoot; Ewers 1968:10); as medicinal heat com presses (Kawaiisu; Zigmond 1981:64); as steam elements in sweat baths (Coeur d'Alêne; Teit 1930a:62); and for extraction of yucca fibers (Tewa; Robbins et al. 1916:51). Hopefully, such facilities retain characteristics that would allow us to distinguish among these various possible functions.

Second, while it appears that pit-hearth cook- 
ing is associated with foods having specific compositions, the data presented here to not demonstrate that foods necessarily must be prepared this way. A better understanding of the pithearth cooking regime, i.e., the temperatures and moisture levels achieved therein (and a similar understanding for stone-boiling), would enable us to better comprehend decisions made by past peoples about food preparation. Such parameters are difficult to mathematically model and therefore replicative experimentation of the type undertaken by Armstrong (1993) will be necessary. ${ }^{3}$

A third step concerns other reference information. Baseline physiological information for human populations that have not coevolved with starchy cereals is necessary. Hopefully, information of this sort will be forthcoming from the Human Genome Project and from research conducted on NIDDM in non-Western populations. Also necessary is baseline information on the lipid and carbohydrate fraction of traditional foods. Most contemporary analyses of food composition report the major components of food as well as mineral and critical amino acid composition. Repeating and expanding the Yanovsky and Kingsbury (1938) study of traditional food composition would take advantage of recent advances in the precision and reliability of carbohydrate fraction measurement. Indeed, even more detailed studies of traditional foods that provide information on starch fraction or fructan form would be helpful. And, information on seasonal levels of animal tissue lipids by species and sex may also be useful. With these several bodies of knowledge, we would be in a better position to appreciate the significance of the various forms of food processing that Stahl (1989) has outlined.
Archaeologically, we see through time important changes in human physiology, such as the reduction in tooth size during the Lower Paleolithic, which complements the appearance of artifacts and features that reflect extrasomatic tissue processing (Brace et al. 1987). At the end of the Middle Paleolithic, there is incontrovertible evidence for the deliberate construction of hearths (James 1989), although whether for denaturing animal protein, detoxifying plant foods (Leopold and Ardrey 1972), or other purposes remains to be addressed. By the early to middle Holocene, there is ample archaeological evidence in the form of pit hearths, grinding technology, and ceramics, as well as the floral and faunal remains themselves, indicating that people were drawing from a very extensive larder. And, throughout the rest of the Holocene, the archaeological record is dominated by evidence that people are resorting to increasingly costly food processing practices to detoxify and maximize the energy value of foods. Our contemporary situation, in which the amount of energy spent to obtain $100 \mathrm{kcal}$ is many times that amount (and is heavily subsidized by fossil fuel use), and in which we are told daily of the health risks of the Western high-fat, highly processed diet, is an ironic continuation of trends that began in the distant past (Eaton and Konner 1985).

An understanding of the coevolution of food resources, processing technologies, and genotypic variation, thus, is increasingly approachable using the durable parts of the archaeological record, even fire-cracked rock and pit hearths. With the anchor of knowledge about food chemistry and heat treatment established here and other such anchors, we can continue to explore the evolution of these coupled phenomena. 


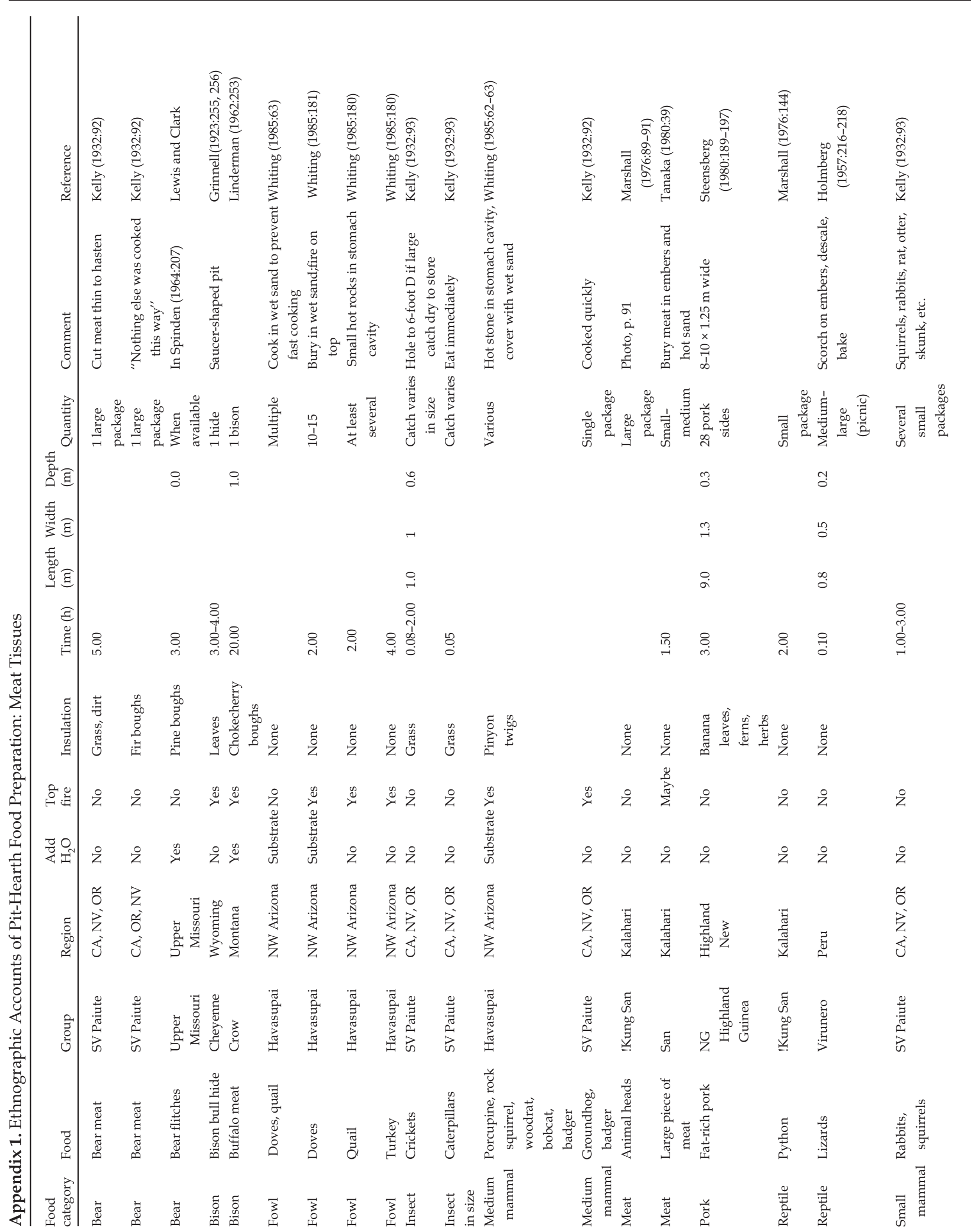




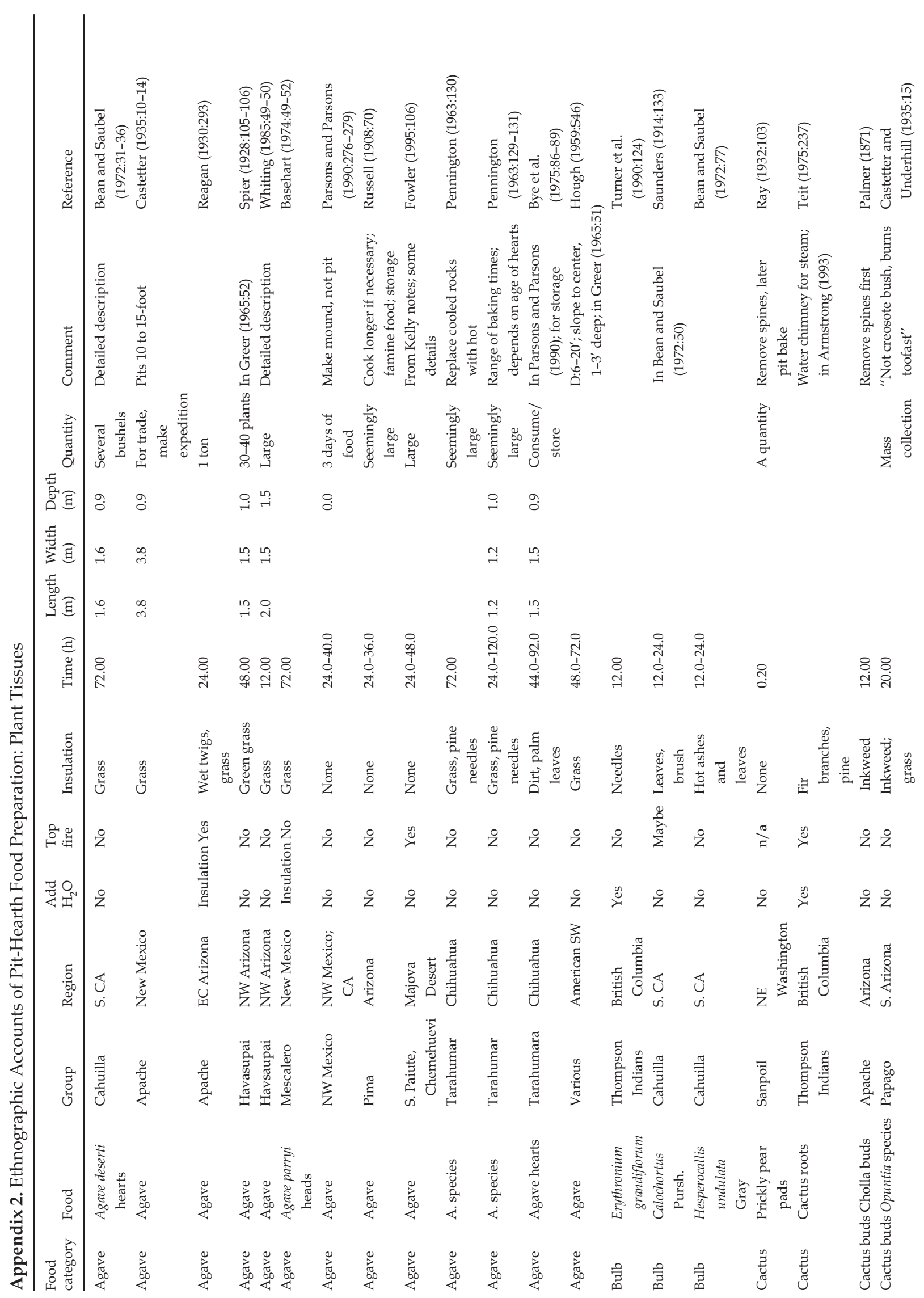




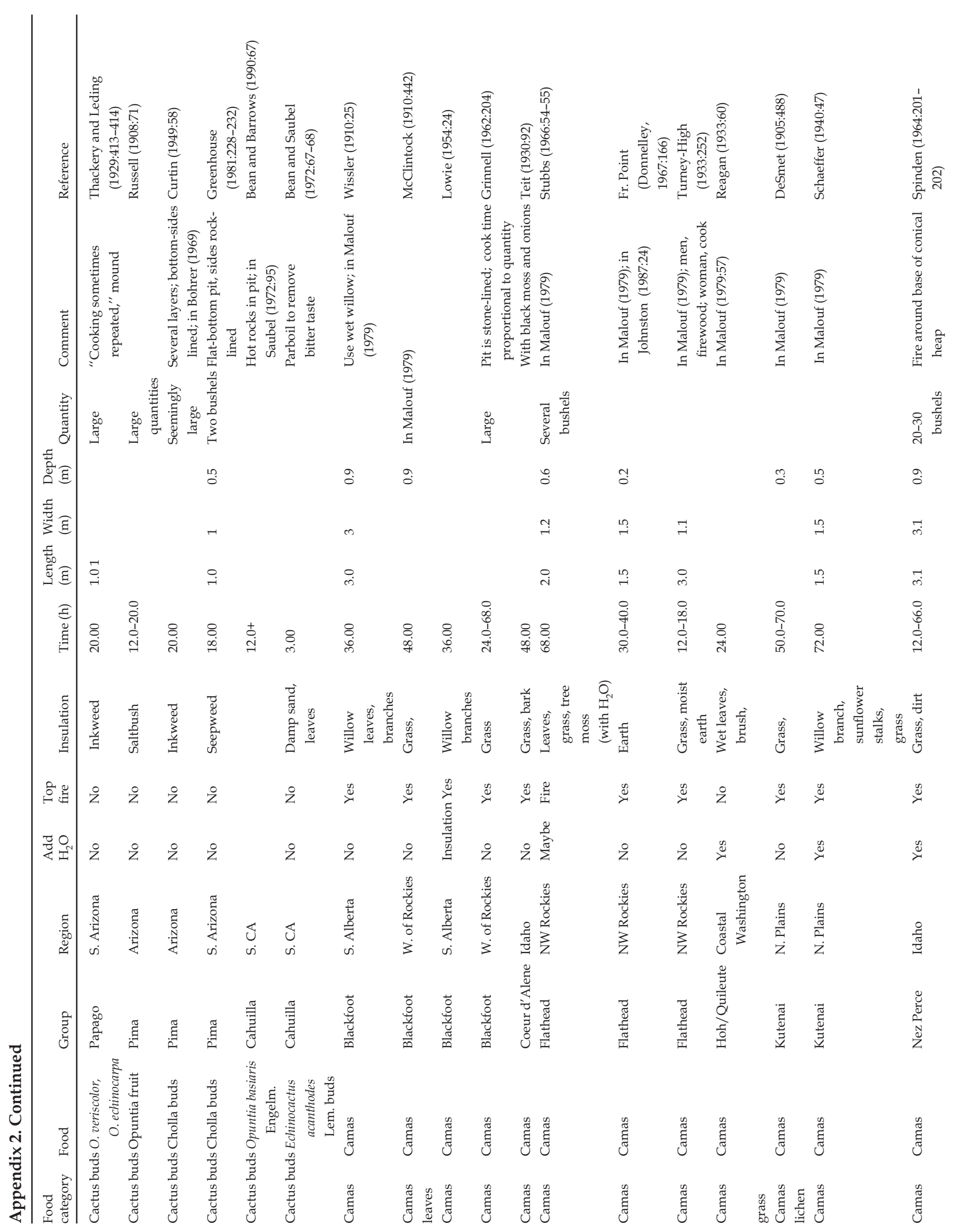




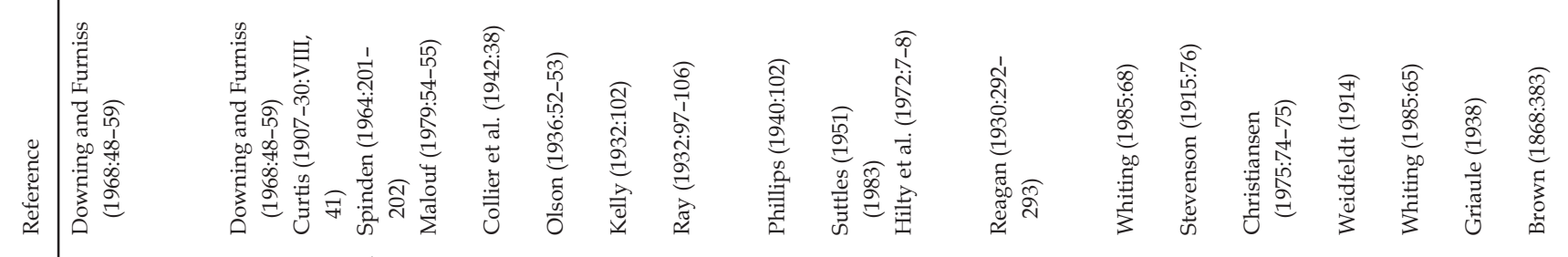

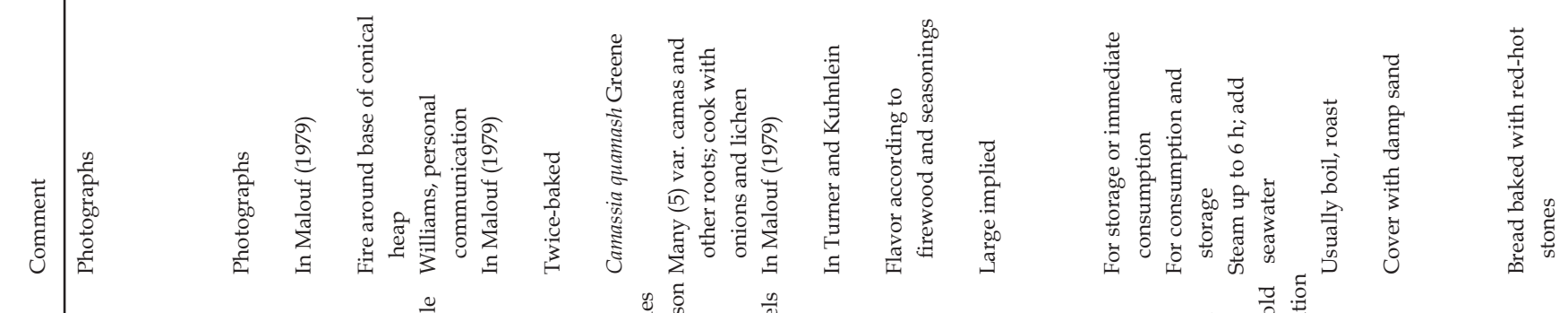

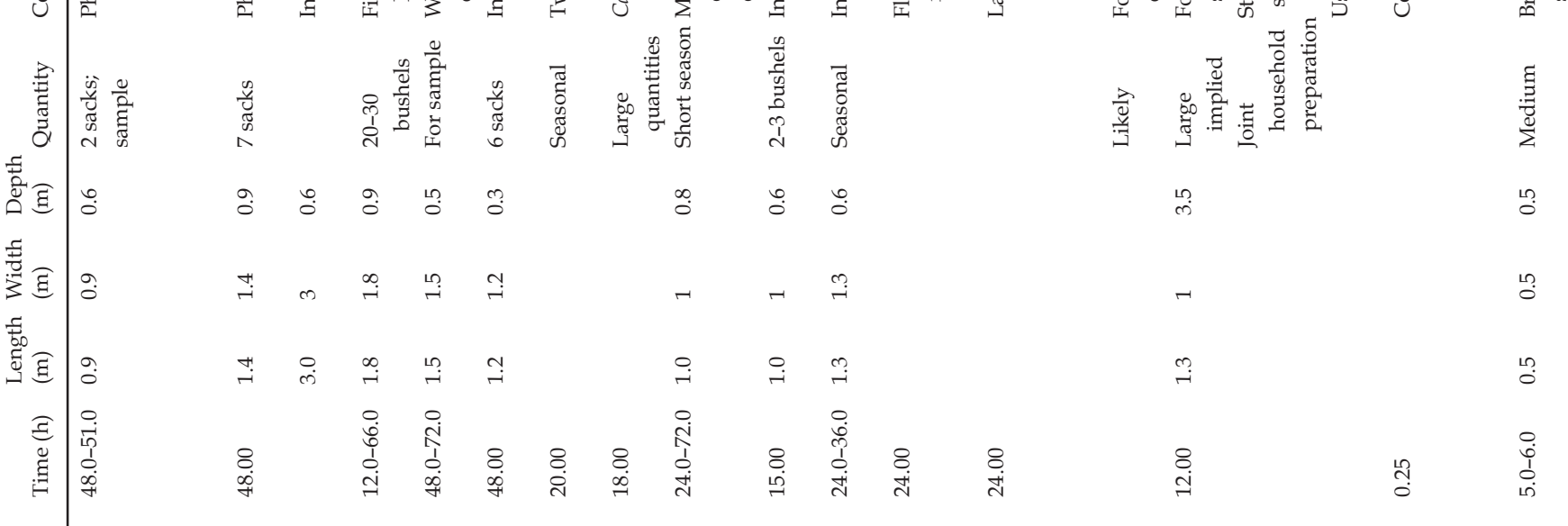

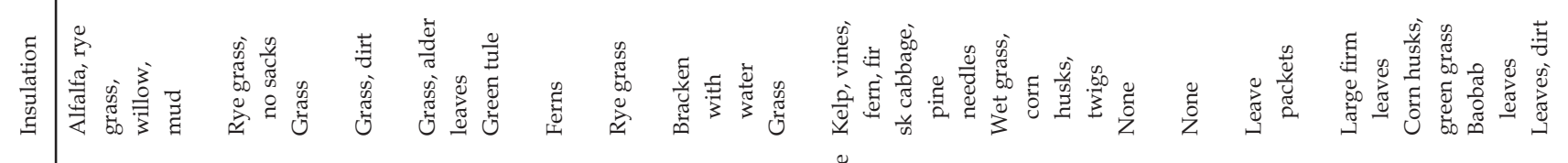
急

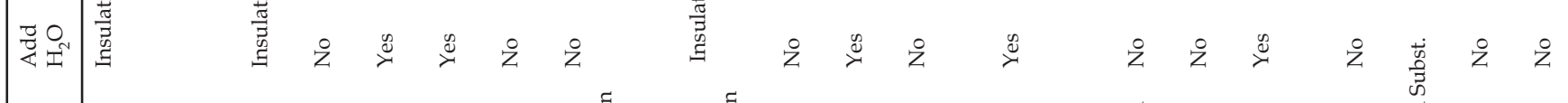

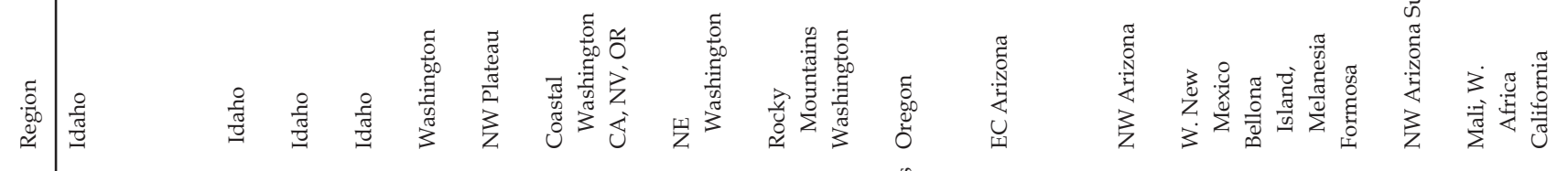

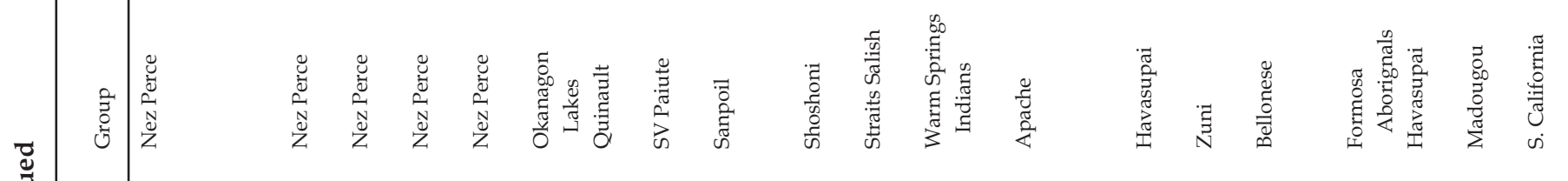

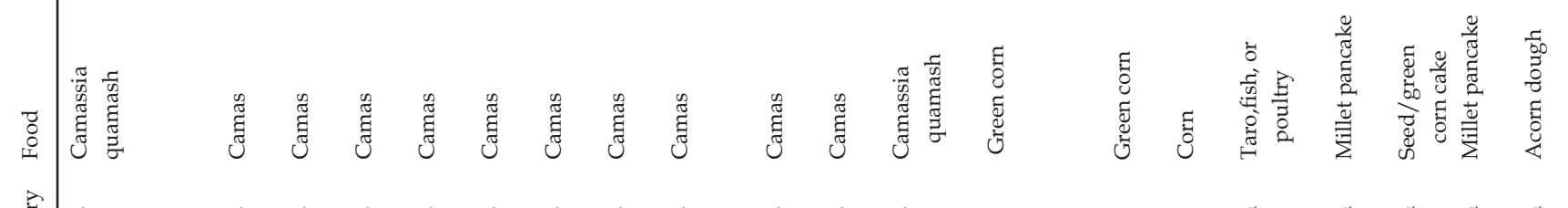

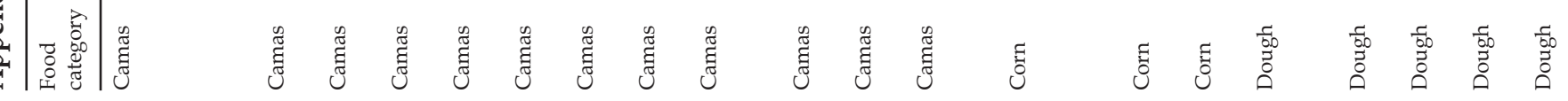




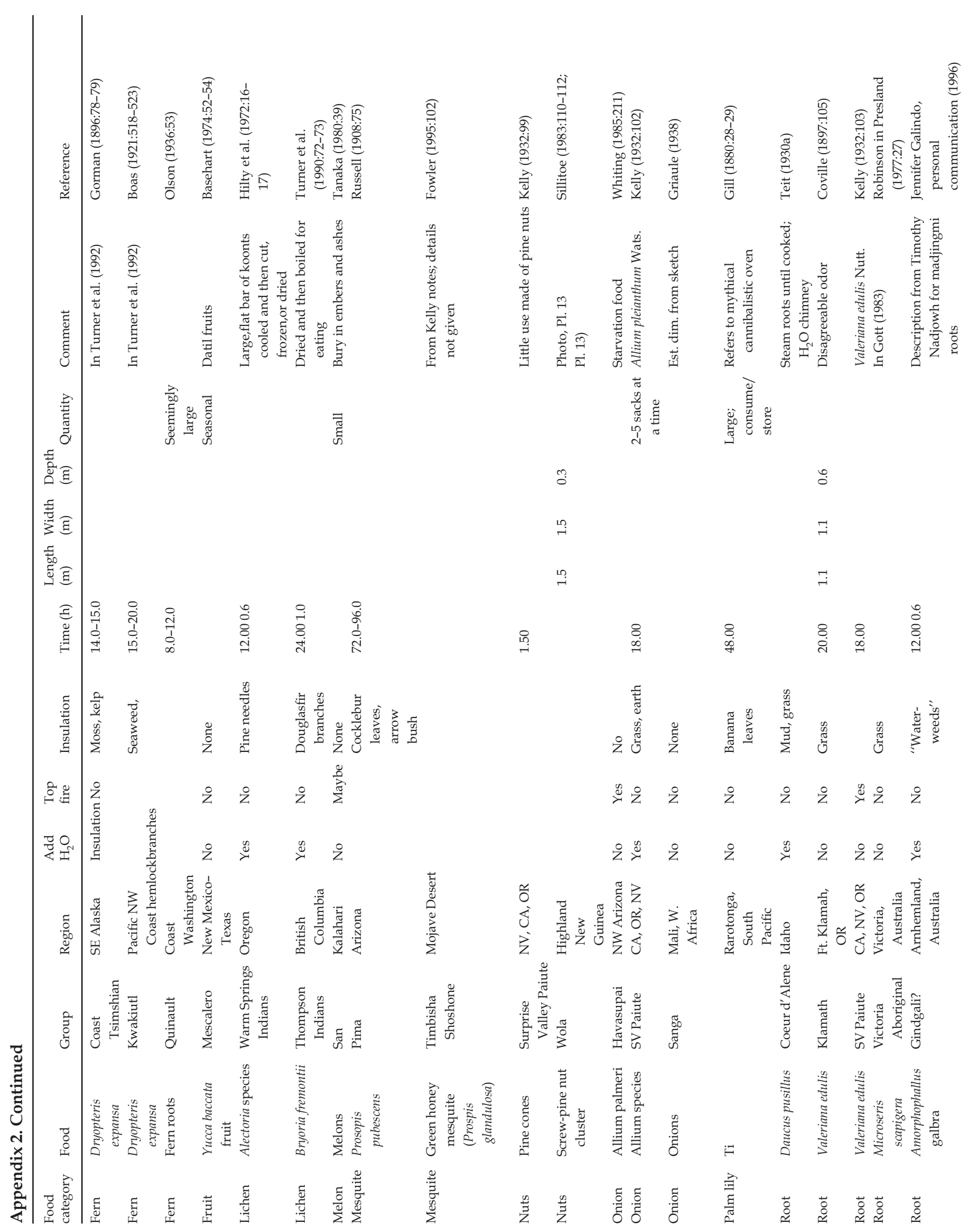




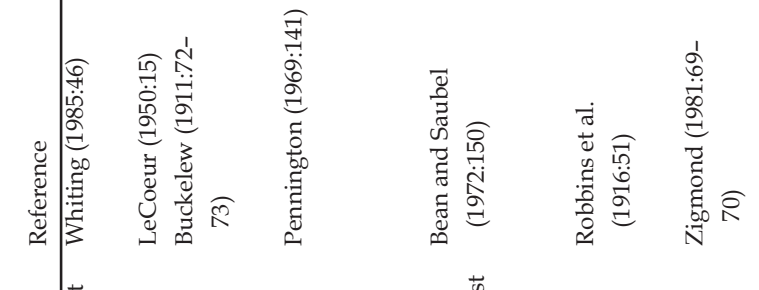

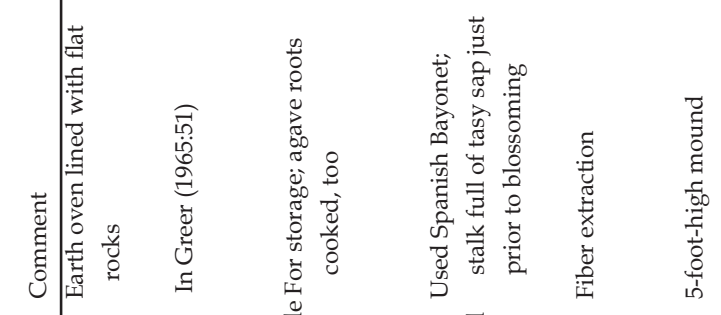

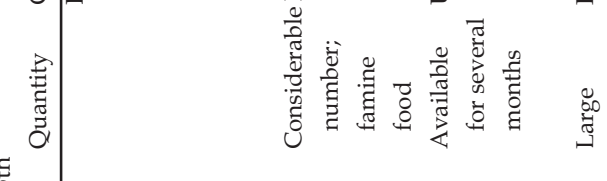

离 Є

$\stackrel{g}{\circ}$

要求 के

芸

菏

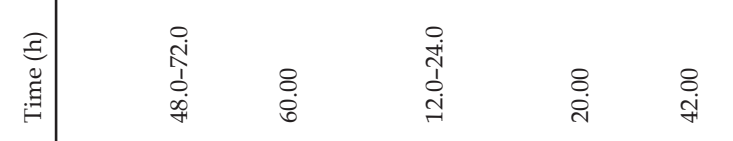

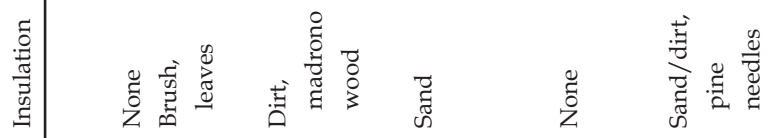

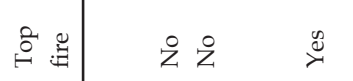

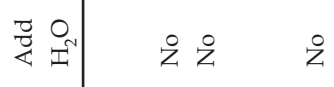

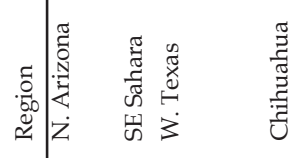

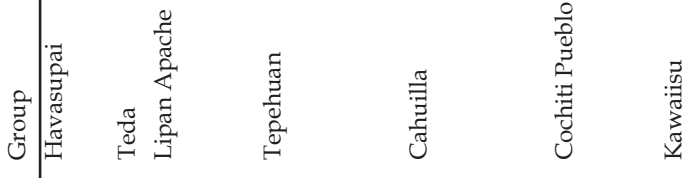

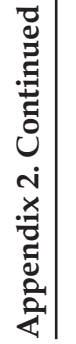

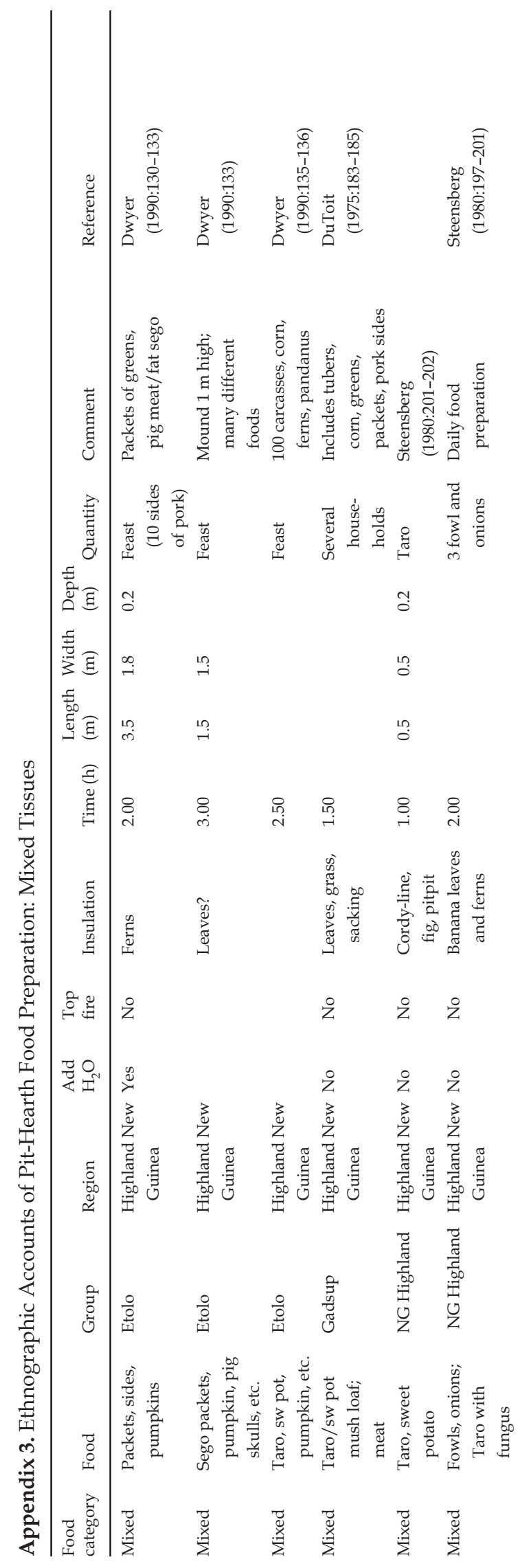




\section{Acknowledgments}

Portions of this paper were presented at the University of Arizona, the University of Missouri-Columbia, the 1995 Annual Meeting of the Plains Anthropological Society in Laramie, and the 1995 Island-in-the-Plains Conference. The comments I received at each venue were most helpful. This paper has further benefited from the input of Steve Black, Peter Bleed, Les Davis, Jim Gibson, Jim Gunnerson, Harriet Kuhnlein, Martha McCullough, Ray Hames (who provided the title, with apologies to Claude Lévi-Strauss), Steve Holen, Alan Osborn, John O'Shea, Karl Reinhard, Michael Schiffer, Marilynn Schnepf, Katherine Spielmann, Alston Thoms, Ann Yaktine, and, most especially, from an anonymous reviewer. I appreciate greatly their help. I also acknowledge the encouragement of Mike Fosha, Julie Francis, Christopher Lintz, Ralph Rowlett, Lisa Sattenspiel, and Patrice Teltser. None of these individuals are responsible for any inadvertent errors. The University of Nebraska-Lincoln Interlibrary Loan facility was called on to perform exceptionally, which it did; I thank those individuals responsible.

\section{References}

Abbott, James, T., and Charles D. Frederick

1990 Proton magnetometer investigations of burned rock middens in west-central Texas: Clues to formation processes, Journal of Archaeological Science 17:535-545.

Ames, Bruce, N.

1983 Dietary carcinogens and anticarcinogens, Science 221:1256-1264.

Anderson, Barbara A.

1989 Composition of foods: Lamb, veal, and game products. Agriculture Handbook No. 8-17, U.S. Department of Agriculture.

Armstrong, Steven

1993 Alder Complex kitchens: Experimental replication of Paleoindian cooking facilities, Archaeology in Montana 34(2):1-66.

Barrows, David Prescott

1900 The ethno-botany of the Coahuilla Indians of southern California. University of Chicago Press, Chicago.

Basehart, Harry W.

1974 Mescalero Apache subsistence patterns and sociopolitical organization. Apachean Indians XII, Garland, NY.

Bean, Lowell John, and Katherin Siva Saubel

1972 Temalpakh: Cahuilla Indian knowledge and usage of plants. Malki Museum Press, Banning, CA.

Bohrer, Vasila H., Hugh C. Cutler, and Jonathan Sauer

1969 Carbonized plant remains from two Hohokam sites, Arizona BB:13:44 and Arizona BB:13:50, The Kiva 35(1):1-10.
Brace, C. Loring, Karen R. Rosenberg, and Kevin D. Hunt

1987 Gradual change in human tooth size in the Late Pleistocene and post-Pleistocene, Evolution 41(4):705-720.

Brand, Janette C., B. Janelle Snow, Gary P. Nabhan, and A. Stewart Truswell

1990 Plasma glucose and insulin responses to traditional Pima Indian meals, American Journal of Clinical Nutrition 51:416-420.

Braun, David P.

1983 Pots as tools. In Archaeological hammers and theories, edited by J. Moore and A. Keene, pp. 107-134. Academic Press, New York.

1987 Coevolution of sedentism, pottery technology, and horticulture in the Central Midwest, 200 B.C.-A.D. 600. In Emergent horticultural economies of the Eastern Woodlands, edited by W. F. Keegan, pp. 153-181. Occasional Paper No. 7, Center for Archaeological Investigations. Southern Illinois University, Carbondale.

Briggs, George M., and Doris Howes Calloway

1984 Nutrition and physical fitness, 11th ed. Holt, Rinehart \& Winston, New York.

Brown, James A.

1989 The beginnings of pottery as an economic process. In What's new? A closer look at the process of innovation, edited by S. E. van der Leeuw and R. Torrence, pp. 203-224. Unwin Hyman, London.

Brown, Robert

1868 On the vegetable products, used by the northwest American Indians as food and medicine, in the arts, and in superstitious rites, Botanical Society of Edinburgh Transactions 9:378-396. Reprinted in An ethnobiology source book, edited by R. I. Ford, Garland, New York, 1986.

Buckelew, F. M.

1911 Buckelew, the Indian captive. Mason Herald, Mason.

Buckley, V. (Ed.)

1990 Burnt offerings: International contributions to burnt mound archaeology. Worldwell, Dublin.

Bye, R. D. Burgess, and A. M. Trias

1975 Ethnobotany of the Western Tarahumara of Chihuahua, Mexico. In Notes on the genus Agave. Botanical Museum Leaflets, Harvard University 24(5):85-112.

Castetter, E. F.

1935 Uncultivated native plants as sources of food. University of New Mexico Bulletin 266, Ethnobotanical Series 1.

Castetter, E. F., and R. M. Underhill

1935 The Ethnobiology of the Papago Indians, University of New Mexico Bulletin Series 4(3):3-84.

Chamberlin, Ralph V.

1964 The Ethno-botany of the Gosiute Indians of Utah, 
Memoirs of the American Anthropological Association 11(5):329-405. Kraus Reprint, New York.

Christiansen, Sofus

1975 Subsistence on Bellona Island (Mungiki). Folia Geographica Danica, 8. København.

Collier, Donald, Alfred E. Hudson, and Arlo Ford

1942 Archaeology of the upper Columbia region, University of Washington Publications in Anthropology 9(1):1-178.

Collins, Veronica R., Gary K. Dowse, Palanitina M. Toelupe, Tofaeono T. Imo, Faalh L. Aloaina, Raymond A. Spark, and Paul Z. Zimmet

1994 Increasing prevalence of NIDDM in the Pacific Island population of Western Samoa over a 13-year period, Diabetes Care 17(4):288-296.

Coville, Frederick V.

1897 Notes on plants used by the Klamath Indians of Oregon, Contributions from the U.S. National Herbarium 5(2):87-108. Reprinted in An ethnobiology source book, edited by R. I. Ford, Garland, New York, 1986.

Crapo, Phyllis A.

1994 Dietary management. In Joslin's Diabetes Mellitus, 13th ed., edited by C. R. Kahn and G. C. Weir, pp. 415-430. Lea and Febiger, Philadelphia.

Crawford, M. A.

1968 Fatty-acid ratios in free-living and domestic animals, The Lancet 1:1329-1333.

Crawford, M. A., M. M. Gale, M. H. Woodford, and N. M. Casped

1970 Comparative studies on fatty acid composition of wild and domestic meats, International Journal of Biochemistry 1:295-305.

Curtin, L. S. M.

1949 By the prophet of the earth. San Vincent Incorporation, Santa Fe.

Darbyshire, B., and R. J. Henry

1981 Differences in fructan content and synthesis in some Allium species, New Phytology 87:249-256.

Davis, Leslie B., Stephen A. Aaberg, and Linda Scott Cummings

1993 Northern Rocky Mountain paleoecology in archaeological, paleobotanical, and paleoethnobotanical perspective. In Plants and their environments: Proceedings of the First Biennial Scientific Conference on the Greater Yellowstone Ecosystem, pp. 33-50. National Park Service, Mammoth, WY.

Del Barco, M.

1973 História natural y crónica de la antigua California. Instituto de Investigaciones Históricas, Univ. Nac. Aut. de México, México, D.F.

Dering, J. Philip

1996 Utilization of geophytes on the Southern Plains: Iden- tification and assessment of a once archaeologically "invisible" plant resource. In Abstracts of the 61st Annual Meeting of the Society for American Archaeology.

Downing, Glenn R., and Lloyd S. Furniss

1968 Some observations on camas digging and baking among present-day Nez Perce, Tebiwa 11(1):48-59.

Driver, Jonathan C.

1990 Meat in due season: The timing of communal hunts. In Hunters of the recent past, edited by L. B. Davis and B. O. K. Reeves, pp. 11-33. Unwin Hyman, London.

DuToit, Brian M.

1975 Akuna: A New Guinea village community. Balkema, Rotterdam.

Dwyer, Peter D.

1990 The pigs that ate the garden. University of Michigan Press, Ann Arbor.

Eastman, Edwin

1879 Seven and nine years among the Camanches and Apaches. Clark Johnson, Jersey City, NJ.

Eaton, S. Boyd, and M. Konner

1985 Paleolithic nutrition, The New England Journal of Medicine 312(5):283-289.

Ebeling, W.

1986 Handbook of Indian foods and fibers of arid America. University of California Press, Berkeley.

Evershed, R. P.

1993 Biomolecular archaeology and lipids, World Archaeology 25(1):74-93.

Ewers, John C.

1968 Indian life on the upper Missouri. University of Oklahoma Press, Norman.

Falk, Carl R., Steve Holen, and Robert Pepperl

1978 A preliminary assessment of archaeological resources in the vicinity of the proposed White River development, Badlands National Monument, South Dakota. Midwest Archaeological Center Occasional Papers in Anthropology No. 5.

FAO

1990 Roots, tubers, plantains and bananas in human nutrition. Food and Agriculture Organization of the United Nations, Rome.

Farris, Glenn J.

1995 Pine nuts as an aboriginal food source in California and Nevada: Some contrasts, Journal of Ethnobiology 2(2):114-122.

Fish, Suzanne K., Paul R. Fish, and John H. Madsen

1990 Analyzing regional agriculture: A Hohokam example. In The archaeology of regions, edited by S. K. Fish and S. A. Kowalewski, pp. 189-218. Smithsonian Institution Press, Washington, DC. 
Fontana, A., B. Hermann, and J. P. Guiraud

1993 Production of high-fructose-containing syrups from Jerusalem artichoke extracts with fructose enrichment through fermentation. In Inulin and inulin-bearing crops, edited by A. Fuchs, pp. 251-258. Elsevier, Amsterdam.

Fowler, Catherine S.

1995 Some notes on ethnographic subsistence systems in Mojavean environments in the Great Basin, Journal of Ethnobiology 151(1):99-117.

Francis, Julie

1995 Root procurement in the upper Green River basin: Archaeological investigations at 48SU1002. Paper presented at the 53rd Annual Plains Anthropological Conference, Laramie.

Freeman, William L., Gwendolyn M. Hosey, Paula Diehr, and Dorothy Gohdes

1989 Diabetes in American Indians of Washington, Oregon, and Idaho, Diabetes Care 12(4):282-288.

Frison, George

1983 Stone circles, stone-filled fire pits, grinding stones and High Plains archaeology. In From microcosm to macrocosm: Advances in tipi ring investigation and interpretation, edited by L. Davis, pp. 81-91. Plains Anthropologist Memoir 19, Lincoln.

Frohne, Dietrich, and Hans Jürgen Pfänder

1983 A colour atlas of poisonous plants. Wolfe Publishing, London.

Garn, Stanley M., and William R. Leonard

1989 What did our ancestors eat?, Nutrition Reviews 47(11):337-345.

Gentry, Howard Scott

1982 Agaves of continental North America. University of Arizona Press, Tucson.

Gill, William Wyett

1880 Savage life in Polynesia. George Didsbury, Wellington.

Gilmore, Melvin R.

1919 Uses of plants by the Indians of the Missouri River region. Republished by the University of Nebraska Press, Lincoln (1975).

Glander, Kenneth E.

1982 The impact of plant secondary compounds on primate feeding behavior, Yearbook of Physical Anthropology 25:1-18.

Gohdes, D. M.

1986 Diabetes in American Indians: A growing problem, Diabetes Care 9(6):609-613.

1995 Diabetes in North American Indians and Alaska natives. In Diabetes in America, 2nd ed. National Institutes of Health Publication No. 95-1468.
Gott, Beth

1983 Murnong-Microseris scapigera: A study of a staple food of Victorian Aborigines, Australian Aboriginal Studies 1983/2:2-18.

Greenhouse, Ruth, Robert E. Gasser, and Jennifer Gish

1981 Cholla bud roasting pits: An ethnoarchaeological example, The Kiva 46(4):227-242.

Greenwood, C. T., and D. N. Munro

1979a Carbohydrates. In Effects of heating on foodstuffs, edited by R. J. Priestley, pp. 35-76. Appl. Sci., London.

1979b Cereals, roots and other starch-based products. In $E f$ fects of heating on foodstuffs, edited by R. J. Priestley, pp. 373-402. Appl. Sci., London.

Greer, John W.

1965 A typology of midden circles and mescal pits, Southwestern Lore 31(3):41-55.

Griaule, Marcel

1938 Jeux dogons. Travaux et memoires de l'Institut d'ethnologie, 32. Institut d'ethnologie, Paris.

Grinnell, George Bird

1962 Blackfoot lodge tales. University of Nebraska Press, Lincoln (originally published in 1892).

1972 The Cheyenne Indians. University of Nebraska Press, Lincoln (originally published in 1923).

Gupta, Anil K., Narinder Kaur, Maninder Kaur, and Rangil Singh

1993 Potential medicinal and nutritional uses of chicory roots and inulin. In Inulin and inulin-containing crops, edited by A. Fuchs, pp. 359-365. Elsevier, Amsterdam.

Hammat, Hallett H.

1976 The Gore Pit site: An Archaic occupation in southwestern Oklahoma and a review of the Archaic stage in the southern Plains, Plains Anthropologist 21(74):245-277.

Harris, D. R., and G. C. Hillman (Eds.)

1989 Foraging and farming: The evolution of plant exploitation. Unwin Hyman, London.

Hart, Jeff

1976 Montana-Native plants and early peoples. Montana Historical Society, Helena.

Hather, J. G.

1991 The identification of charred archaeological remains of vegetative parenchymous tissue, Journal of Archaeological Science 18:661-675.

Hayden, Brian

1990 Nimrods, piscators, pluckers, and planters: The emergence of food production, Journal of Anthropological Archaeology 9:31-69. 
Hellendoorn, E. W., M. G. Noordhoff, and J. Slagman

1970 Digestibility in vitro of dry mashed potato products, Journal of Science and Food Agriculture 26:1461-1468.

Hendry, George A. F., and Rebecca K. Wallace

1993 The origin, distribution, and evolutionary significance of fructans. In Science and Technology of Fructans, edited by M. Suzuki and N. J. Chatterton, pp. 119-139. CRC Press, Boca Raton, FL.

Hilty, I., E. M. Peters, M. Edwards, and L. T. Miller

1972 Nutritive values of native foods of Warm Springs Indians. Extension Circular No. 809. Extension Service, Oregon State University, Eugene.

Hodder, M. A., and L. H. Barfield

1991 Burnt mounds and hot stone technology. Sandwell Metropolitan Council Borough, West Midlands, Ireland.

Hodge, Allison M., Janice Montgomery, Gary K. Dowse, Barnabas Mavo, Tahlia Watt, and Paul Z. Zimmet

1996 A case-control study of diet in newly diagnosed NIDDM in the Wanigela people of Papua New Guinea, Diabetes Care 19(5):457-462.

Holmberg, Allan R.

1957 Lizard hunts on the north coast of Peru, Fieldiana Anthropology 36(9):203-220.

Holmes, Z. A., and M. Woodburn

1981 Heat transfer and temperature of foods during processing, CRC Critical Reviews in Food Science and Nutrition 14:231-294.

Hough, Walter

1959 Mescal. In Handbook of American Indians north of Mexico, Part I, edited by F. W. Hodge. Bureau of American Ethnology, Bulletin 30.

Incoll, L. D., and G. D. Bonnett

1993 The occurrence of fructan in food plants. In Inulin and inulin-containing crops, edited by A. Fuchs, pp. 309322. Elsevier, Amsterdam.

Incoll, L. D., G. D. Bonnett, and Beth Gott

1989 Fructans in the underground storage organs of some Australian plants used for food by Aborigines, Journal of Plant Physiology 134:196-202.

Jackson, Fatimah Linda Collier

1991 Secondary compounds in plants (allelochemicals) as promoters of human biological variability, Annual Reviews in Anthropology 20:505-546.

James, Steven R.

1989 Hominid use of fire in the Lower and Middle Pleistocene, Current Anthropology 30(1):1-16.

Johns, Timothy

1989 A chemical-ecological model of root and tuber domestication in the Andes. In Foraging and farming: The evolution of plant exploitation, edited by D. R. Har- ris and G. C. Hillman, pp. 504-519. Unwin Hyman, London.

Johns, Timothy, and Isao Kubo

1988 A survey of traditional methods employed for the detoxification of plant foods, Journal of Ethnobiology 8(1):81-129.

Johnson, Ann

1996 The Fog Creek Archaeological Sites, Badlands National Park. Intermountain Field Area, National Park Service. Manuscript on file with the author.

Johnston, Alex

1987 Plants and the Blackfoot. Occasional Paper 15, Lethbridge Historical Society, Lethbridge, Alberta.

Kelly, Isabel T.

1932 Ethnography of the Surprise Valley Paiute, University of California Publications in American Archaeology and Ethnology 31(3):67-210.

Knowler, W. C., P. H. Bennet, R. F. Hamman, and M. Miller 1978 Diabetes incidence and prevalence in Pima Indians: A 19-fold greater incidence than in Rochester, Minn., American Journal of Epidemiology 108:497-504.

Kuhnlein, Harriet V., Donna Appavoo, Natalia Morrison, Rula Soueida, and Patricia Pierrot

1994 Use and nutrient composition of traditional Sahtú (Hareskin) Dene/Métis foods, Journal of Food Composition and Analysis 7:144-157.

Laferriere, J. E.

1992 Cultural and environmental response to drought among the Mountain Pima, Ecology of Food and Nutrition 28:1-9.

Larsen, Clark Spencer

1995 Biological changes in human populations with agriculture, Annual Review of Anthropology 24:185-213.

LeCoeur, Charles

1950 Dictionaire ethnographique téda precede d'un lexique français-téda. Institute Français d'Afrique-Noire, Memoires 9. Librairie Larose, Paris.

Leopold, A. Carl, and Robert Ardrey

1972 Toxic substances in plants and the food habits of early man, Science 176:512-514.

Linderman, Frank B.

1962 Plenty-coups, chief of the Crows. University of Nebraska Press, Lincoln.

Linton, Ralph

1944 North American cooking pots, American Antiquity 9:369-380.

Lowie, Robert H.

1909 The northern Shoshone, Anthropological Papers of the American Museum of Natural History 2(2):165-307. 
1924 Notes on Shoshonean ethnography, Anthropological Papers of the American Museum of Natural History 20:185-314.

1954 Indians of the Plains. McGraw-Hill, New York. (Reprinted in 1982 by the University of Nebraska Press, Lincoln.)

Malouf, Richard T. 334:233-241.

1979 Camas and the Flathead Indians of Montana. In Contributions to Anthropology No. 7. Department of Anthropology, University of Montana. 62:671-680.

Mandelbaum, David G.

1979 The Plains Cree. Canadian Plains Studies 9. Canadian Plains Research Center, University of Regina, Regina.

Marchello, M. J., W. D. Slanger, D. B. Milne, A. G. Fisher, and P. T. Berg

1989 Nutrient composition of raw and cooked Bison bison, Journal of Food Composition and Analysis 2:177-185.

Marshall, Lorna

1976 The !Kung of Nyae Nyae. Harvard University Press, Cambridge, MA.

McKey, Doyle

1979 The distribution of secondary compounds within plants. In Herbivores: Their interaction with secondary plant metabolites, edited by G. A. Rosenthal and D. H. Janzen, pp. 55-133. Academic Press, New York.

McWilliams, Margaret

1993 Foods: Experimental perspectives, 2nd ed. Macmillan, New York.

Medved, Eva

1986 Food preparation and theory. Prentice-Hall, Englewood Cliffs, NJ.

Meier, H., and J. S. G. Reid

1982 Reserve polysaccharides other than starch in higher plants. In Encyclopedia of plant physiology, New Series Vol. 13A, Plant carbohydrates I: Intercellular carbohydrates, edited by F. A. Loewus and W. Tanner, pp. 419-471. Springer-Verlag, Berlin.

Meston, Larry

1976 Archaeological investigations in the White River region, northwest Nebraska. Department of Anthropology, University of Nebraska, Technical Report 76-12.

Neel, James V.

1962 Diabetes mellitus: A "thrifty" genotype rendered detrimental by "progress"?, American 1990 Journal of Human Genetics 14:353-362.

1982 The thrifty genotype revisited. In The genetics of diabetes mellitus, Serono Symposium No. 47, edited by J. Köbberling and R. Tattersall, pp. 283-293. Academic Press, London.
O’Dea, Kerin

1986 Aboriginal health and changes in lifestyles, Australian Family Physician 15:875-891.

1991 Traditional diet and food preferences of Australian Aboriginal hunter-gatherers, Philosophical Transactions of the Royal Society of London B 334:233-241.

Ó Drisceoil, Diarmuid A.

1988 Burnt mounds: Cooking or bathing?, Antiquity 62:671-680

Ohyama, T., O. Ito, S. Yasuyoshi, T. Ikarashi, K. Minamisawa, M. Kubota, T. Tsukihashi, and T. Asami

1990 Composition of storage carbohydrate in tubers of yacon (Polymnia sonchifolia), Soil Science and Plant Nutrition 36(1):167-171.

O'Kelly, Michael J.

1953 Excavations and experiments in ancient Irish cooking-places, Royal Society of Antiquaries of Ireland 84:105-155.

Olson, Ronald L.

1936 The Quinault Indians. In University of Washington Publications in Anthropology 6.

Omar, Mahomed A. K., Mahomed A. Seedat, Robin B. Dyer, Ayesha A. Motala, Lucinda T. Knight, and Peter J. Becker

1994 South African Indians show a high prevalence of NIDDM and bimodality in plasma glucose distribution patterns, Diabetes Care 17(1):70-73.

O'Shea, John

1989 The role of wild resources in small-scale agricultural systems: Tales from the Lakes and the Plains. In Bad year economics: Cultural responses to risk and uncertainty, edited by P. Halstead and J. O'Shea, pp. 57-67. Cambridge University Press, Cambridge, UK.

Palmer, Edward

1871 Food products of the North American Indians. In U.S. Department of Agriculture, Report of the Commissioner for 1870, pp. 404-428. (Reprinted in An ethnobiology source book, edited by R. I. Ford, Garland, New York, 1986.)

Parsons, Jeffrey R., and Mary H. Parsons

1990 Maguey utilization in Highland Central Mexico: An archaeological ethnography. Anthropological Papers No. 82, Museum of Anthropology, University of Michigan.

Penfield, Marjorie P., and Ada Marie Campbell

1990 Experimental food science, 3rd ed. Academic Press, San Diego.

Pennington, Campbell W.

1963 The Tarahumar of Mexico: Their environment and material culture. University of Utah Press, Salt Lake City. 
1969 The Tepehuan of Chihuahua: Their material culture. University of Utah Press, Salt Lake City.

Pollock, C. J., and N. J. Chatterton

1988 Fructans. In The biochemistry of plants, Vol. 14, Carbohydrates, edited by Jack Preiss, pp. 109-140. Academic Press, San Diego.

Ray, Verne F.

1932 The Sanpoil and the Nespelem: Salishan peoples of northeastern Washington, University of Washington Publications in Anthropology 5:1-237.

Reagan, Albert B.

1930 Notes on the Indians of the Fort Apache region, Anthropological Papers of the American Museum of Natural History 31:part 5.

Reeve, Stuart A.

1986 Food crops and prehistoric social process in the Snake River headquarters, northwestern Wyoming. Unpublished Ph.D. dissertation, Department of Anthropology, State University of New York, Albany.

Reeves, Brian O. K.

1990 Communal bison hunters of the Northern Plains. In Hunters of the recent past, edited by L. B. Davis and B. O. K. Reeves, pp. 168-194. Unwin Hyman, London.

Robbins, Wilfred W., John P. Harrington, and Barbara Freire-Marreco

1916 Ethnobotany of the Tewa Indians. Bureau of American Ethnology Bulletin 55, Washington, DC.

Roberfroid, M.

1993 Dietary fiber, inulin, and oligofructose: A review comparing their physiological effects, Critical Reviews in Food Science and Nutrition 33(2):103-148.

Rombauer, Irma S., and Marion Rombauer Becker

1975 Joy of cooking. Bobbs-Merrill, Indianapolis.

Russell, Frank

1908 The Pima Indians. Bureau of American Ethnology 26 (1904-1905), Washington, DC (reprinted in 1975, University of Arizona Press).

Saunders, Charles Francis

1914 With the flowers and trees in California. Robert M. McBride and Co., New York.

Schiffer, Michael B., and James M. Skibo

1987 Theory and experiment in the study of technological change, Current Anthropology 28(5):595-622.

Schultz, C. Bertrand, and H. T. U. Smith (Eds.)

1965 INQUA VIIth Congress. Guidebook for Field Conference D Central Great Plains. Nebraska Academy of Science, Lincoln.

Sheldon, A. E.

1905 Ancient Indian fireplaces in South Dakota badlands, American Anthropologist 7:44-48.
Sillitoe, Paul

1983 Roots of the earth. Manchester University Press, Manchester, UK.

Southgate, D. A. T.

1991 Determination of food carbohydrates, 2nd ed. Elsevier Applied Science, London.

Speth, John D.

1983 Bison kills and bone counts. University of Chicago Press, Chicago.

Speth, John D., and Katherine A. Spielmann

1983 Energy source, protein metabolism, and hunter-gatherer subsistence strategies, Journal of Anthropological Archaeology 2:1-31.

Spier, Leslie

1928 Havasupai ethnography. Anthropological Papers of the American Museum of Natural History, No. 29.

Spinden, Herbert Joseph

1964 The Nez Perce' Indians, Memoirs of the American Anthropological Association 11(3):165-274. Kraus Reprint, New York.

Stahl, Ann B.

1984 Hominid dietary selection before fire, Current Anthropology 25(2):151-168.

1989 Plant-food processing: Implications for dietary quality. In Foraging and farming: The evolution of plant exploitation, edited by D. R. Harris and G. C. Hillman, pp. 171-196. Unwin Hyman, London.

Steensberg, Axel

1980 New Guinea gardens. Academic Press, London.

Stern, Michael P., J. Ava Knapp, Helen P. Hazuda, Steven M. Haffner, Judith K. Patterson, and Braxton D. Mitchell

1991 Genetic and environmental determinants of type II diabetes in Mexican Americans, Diabetes Care 14(7):649-654.

Stevenson, Matilda Coxe

1915 Ethnobotany of the Zuñi Indians. Bureau of American Ethnology 30 (1908-1909), Washington, DC.

Steward, Julian $\mathrm{H}$.

1933 Ethnography of the Owens Valley Paiute, University of California Publications on American Archaeology and Ethnology 33(3):233-350.

Stinson, Sara

1992 Nutritional adaptation, Annual Reviews in Anthropology 21:143-170.

Szathmáry, Emöke J. E.

1994 Non-insulin dependent diabetes mellitus among aboriginal North Americans, Annual Review of Anthropology 23:457-482. 
Takac, Paul R., and Michael B. Collins

1995 New directions in archaeomagnetism: Analyzing the context of burned rock features. Geological Society of America, Abstracts with Programs 27(6):A-301.

Tanaka, Jiro

1980 The San hunter-gatherers of the Kalahari. University of Tokyo Press, Tokyo.

Teit, James A.

1930a Salishan tribes of the Western Plateaus. In 44th Annual Report of the Bureau of American Ethnology, 19271928, pp. 23-439. Washington, DC.

1930b Ethnobotany of the Thompson Indians of British Columbia (edited by Elsie V. Steedman). In 44th Annual Report of the Bureau of American Ethnology, 1927-1928, pp. 441-522. Washington, DC.

Thackery, Frank, and A. R. Leding

1929 The giant cactus of Arizona: The uses of its fruit and other cactus fruits of the Indians, Journal of Heredity 20:400-414.

Thoms, Alston V.

1989 The northern roots of hunter-gatherer intensification: Camas and the Pacific Northwest. Unpublished Ph.D. dissertation, Department of Anthropology, Washington State University, Pullman.

Thorburn, Anne W., Janette C. Brand, and A. Stewart Truswell

1987 Slowly digested and absorbed carbohydrate in traditional bushfoods: A protective factor against diabetes?, American Journal of Clinical Nutrition 45:98-106.

Turner, Nancy J., and Harriet V. Kuhnlein

1983 Camas (Camassia spp.) and riceroot (Fritillaria spp.): Two liliaceous "root" foods of the Northwest Coast Indians, Ecology of Food and Nutrition 13:199-219.

Turner, Nancy J., Leslie M. Johnson Gottesfeld, Harriet V. Kuhnlein, and Adolf Ceska

1992 Edible wood fern rootstocks of Western North America: Solving an ethnobotanical puzzle, Journal of Ethnobiology 12(1):1-34.

Turner, Nancy J., Laurence C. Thompson, M. Terry Thompson, and Annie Z. York

1990 Thompson Ethnobotany. Royal British Columbia Museum Memoir No. 3.

Vogel, Manfred

1993 A process for the production of inulin and its hydrolysis products from plant material. In Inulin and inulin-bearing crops, edited by A. Fuchs, pp. 65-76. Elsevier, Amsterdam.

Vukov, K., M. Erdélyi, and E. Pichler-Magyar

1993 Preparation of pure inulin and various inulin-containing products from Jerusalem artichoke for human consumption and for diagnostic use. In Inulin and in- ulin-bearing crops, edited by A. Fuchs, pp. 341-346. Elsevier, Amsterdam.

Wandsnider, LuAnn, Heidi Athen, Jennifer Galindo, and George MacDonell

1995 University of Nebraska - Lincoln summer field school in archaeology 1994 report to the Nebraska National Forest. Manuscript in the possession of the authors.

Welch, Paul D., and C. Margaret Scarry

1995 Status-related variation in foodways in the Moundville chiefdom, American Antiquity 60(3):397-420.

Wendorf, Michael, and Ira D. Goldfine

1991 Archaeology of NIDDM: Excavation of the "thrifty" genotype, Diabetes 40:161-165.

Whiting, Alfred F.

1985 Havasupai habitat: A. F. Whiting's ethnography of a traditional Indian culture, edited by S. A. Weber and P. D. Seaman. University of Arizona Press, Tucson.

Wiedfeldt, O.

1914 Wirtschaftliche, rechtliche und soziale Grundtatsachen und Grundformen der Atayalen auf Formosa. In Mitteilungen der Deutschen Gesellschaft für Natur- und Völkerkunde Ostasiens, Vol. XV, Part C., pp. 7-55. Tokyo.

Yamazaki, H., and K. Matsumoto

1993 Production of fructo-oligosaccharide-rich fructose syrup. In Inulin and inulin-bearing crops, edited by A. Fuchs, pp. 355-358. Elsevier, Amsterdam.

Yanovsky, E., and R. M. Kingsbury

1938 Analysis of some Indian food plants, Association of Official Agricultural Chemists 21(4):648-665.

Zardini, Elsa

1991 Ethnobotanical notes on "yacon," Polymnia sonchifolia (Asteraceae), Economic Botany 45(1):72-85.

Zigmond, Maurice L.

1981 Kawaiisu ethnobotany. University of Utah Press, Salt Lake City.

\section{Notes}

${ }^{1}$ It is unlikely that the variation is owed to heat treatment. A comparison of lipid-protein ratios between raw and cooked tissues in the Anderson (1989) series (cooked values not presented here) indicates that while the absolute weights of tissue change with cooking, the lipid-protein ratio remains stable $(r=1.00, p=0.000, n=14)$.

${ }^{2}$ Gill goes on to recount a tale of sabotage, in which a community was invited to a $t i$ feast, but then was tumbled into the oven to be themselves roasted.

3 The Headwaters Experimental Group out of the University of Texas at Austin has recently initiated a concerted effort in this area. 